\title{
Reports of Finnish corticolous Aphyllophorales (Basidiomycetes)
}

\author{
HEIKKI KOTIRANTA and REIMA SAARENOKSA
}

\begin{abstract}
KOTIRANTA, H. \& SAARENOKSA, R. 1990: Reports of Finnish corticolous Aphyllophorales (Basidiomycetes). — Karstenia 30:43-69.

Twenty-seven new, rare or little collected species of the Aphyllophorales, mainly Corticiaceae, are reported from Finland. The following species are new to Finland: Ceratobasidium pseudocornigerum M.P. Christ., Confertobasidium olivaceoalbum (Bourd. \& Galz.) Jül., Hypochnicium erikssonii Hallenb. \& Hjortst., $H$. subrigescens Boid., Litschauerella clematitis (Bourd. \& Galz.) J. Erikss. \& Ryv., Phlebiella lloydii (Liberta) Hjortst. \& Larsson, Sistotrema heteronemum (J. Erikss.) Strid, Sistotremella perpusilla Hjortst., Tubulicrinis globisporus Larsson \& Hjortst. and T. strangulatus Larsson \& Hjortst. Information on the distribution is included for some species in the genera Asterostroma, Botryobasidium, Hyphoderma, Hyphodontia, Hyphodontiella, Hypochniciellum, Jaapia, Kavinia, Lobulicium, Phlebiella, Sistotremastrum, Steccherinum, Trechispora and Tubulicrinis. Drawings of 21 species are presented.
\end{abstract}

Key words: Aphyllophorales, Corticiaceae, distribution

Heikki Kotiranta, Water and Environment Research Office (Nature Conservation), Water and Environment Research Institute, P.O. Box 250, SF-00101 Helsinki, Finland Reima Saarenoksa, Department of Botany, University of Helsinki, Unioninkatu 44, SF00170 Helsinki, Finland

The earlier studies of the Corticiaceae in Finland are listed by Kotiranta and Larsson (1990). The following new reports come mainly from southern Finland, where the author Saarenoksa has collected, especially in the vicinity of the city of Helsinki, and from northern Finland, being based on the collections of Kotiranta. The few notes from central Finland were made by the senior author, and only a few records are based on other herbarium specimens.

\section{Material and methods}

The studied material is preserved in the herbaria $\mathrm{H}$, GB or OULU (see Holmgren et al. 1981) and/or in the reference collections of Heikki Kotiranta (H.K.).

The mounting media used in the microscopy were $\mathrm{CB}$, IKI and $\mathrm{KOH}(5 \%)$; for the abbreviations see Niemelä (1985). The biological provinces of Finland used are mapped in Niemelä (1982), and the collect- ing sites are indicated according to the Finnish national uniform grid system which, is presented by Heikinheimo and Raatikainen (1971). The nomenclature mostly follows Hjortstam (1984) and Hjortstam et al. (1988), and the species are arranged in alphabetical order. Synonyms are mentioned only if they deviate from those given in the papers mentioned above. In this paper the words $P$ icea and spruce refer to Picea abies (L.) H. Karsten and Pinus and pine to Pinus sylvestris L.

\section{List of species}

\section{Asterostroma laxum Bres. - Fig. 1.}

Reported earlier from Finland by Eriksson and Strid (1969) and Ulvinen et al. (1981, Asterostroma cf. laxum). Fruit body resupinate, smooth, fairly thick (less than $1 \mathrm{~mm}$ ), loosely attached, pale brownish. 

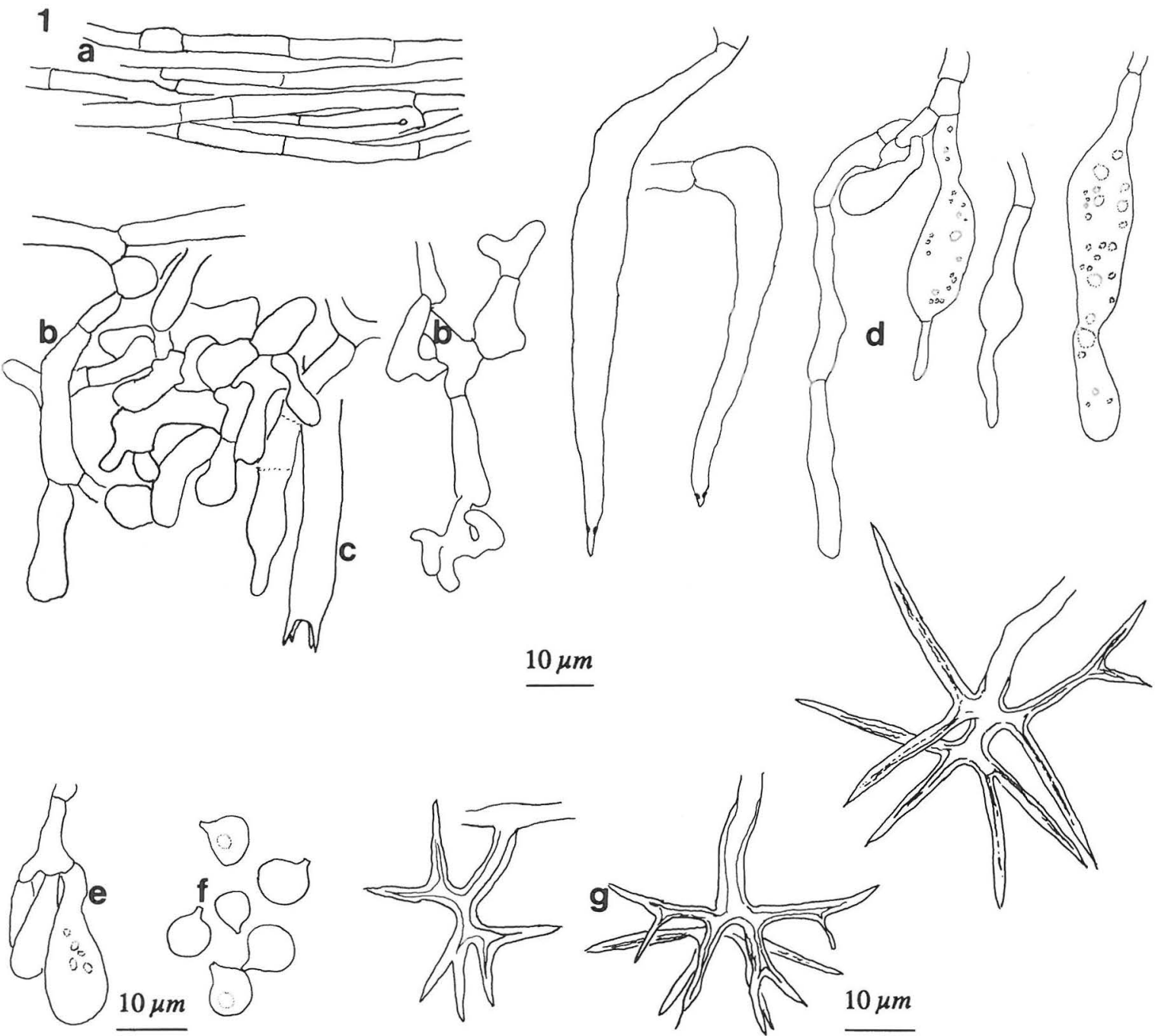

Fig. 1. Asterostroma laxum Bres. a) basal hyphae, b) context, c) basidia, d) gloeocystidia, e) basidioles, f) spores, g) asterosetae (specimen Saarenoksa 17389, H, H.K.).

Hyphal system monomitic. Basal hyphae attached to the matrix, thin-walled, simple septate, parallel, sparingly branched, 3-3.5 $\mu \mathrm{m}$ wide. Other subicular hyphae and subhymenial hyphae short, thin-walled, richly branched, randomly oriented, very variable in shape. Asterosetae common throughout the fruit body, light golden brown, $\mathrm{CB}-$ (very young $\mathrm{CB}+$ ), IKI-. Gloeocystidia numerous, tubular, flexuose, thin-walled, very variable in shape, (19-)35-80 x (4.5-)5-9 $\mu \mathrm{m}$, often schizopapillate, with a very faint amyloid reaction at the papillary neck. Basidia almost missing in our specimen (only one detected), but according to Parmasto (1971) and Hallenberg
(1985) they are 30-97 × 6-9 $\mu \mathrm{m}$, basally simple septate, with four sterigmata. Spores globose or somewhat flattened 5.5-7.5 $\mu \mathrm{m}$, thin-walled, CB-, amyloid, and with a prominent, up to $2 \mu \mathrm{m}$ long apiculus.

Rare, but widely distributed. In Europe reported from Sweden (Eriksson 1948, 1958a, Hallenberg 1985, Larsson 1986), Norway (Hallenberg 1973), Denmark (Christiansen 1960, Hallenberg 1985), Estonia (Parmasto 1971), Germany (Doll 1977, 1981), Great Britain (Hallenberg 1973), Switzerland (Breitenbach \& Kränzlin 1986), France (Bourdot \& Galzin 1928) and outside Europe from Canada (Bondarceva \& Parmasto 1986). 
A. laxum has a wide range of host species; it has been reported from Picea (Parmasto 1971), Pinus (Eriksson 1958a, Eriksson \& Strid 1969), Castanea (Bourdot \& Galzin 1928), Betula (Eriksson 1948), Quercus (Hallenberg 1972-73), Calluna vulgaris, Vaccinium myrtillus (Christiansen 1960) and the polypore Inonotus radiatus (Sow.: Fr.) Karst. (Parmasto 1971).

\section{Specimen examined}

Finland. Uusimaa: Tuusula, Lahela, decorticated, fairly strongly decayed coniferous wood (Pinus?) of an old collapsed barn in deciduous grass-herb forest, together with Resinicium bicolor (Alb. \& Schw.: Fr.) Parm., Grid 27E 6698:388, 27.VIII.1989 Saarenoksa 17389 (H, H.K.).

Botryobasidium intertextum (Schw.) Jül. \& Stalpers - Fig. 2.

\section{B. angustisporum (Boid.) Talbot.}

Reported earlier from Finland by Eriksson and Strid (1969). Fruit body resupinate, at first thin, hypochnoid, white; later almost pellicular, yellowish.

Hyphal system monomitic. Basal hyphae with smooth and thickened walls, clamped, 7.5-8 $\mu \mathrm{m}$ wide. Other subicular hyphae thin-walled, fairly richly ramified at right angles, simple septate, 5$7 \mu \mathrm{m}$ wide. Subhymenial hyphae thin-walled, clamped, 5-7 $\mu \mathrm{m}$ wide. All hyphae CB+. Cystidia none. Basidia mostly subcylindrical, sometimes constricted, (13-)15-21(-23) × 5-6.5 $\mu \mathrm{m}$ wide, basally clamped, with six sterigmata. Spores navicular, 7.0 $9.5 \times 1.8-2.8 \mu \mathrm{m}, \mathrm{L}=8.3, \mathrm{~W}=2.3, \mathrm{Q}=2.9-4.5, \mathrm{Q}=$ 3.7 (Saarenoksa 18689), $\mathrm{n}=30 ; 6.5-9.0 \times 1.8$ $2.8 \mu \mathrm{m}, \mathrm{L}=7.5, \mathrm{~W}=2.1, \mathrm{Q}=3.0-4.2, \mathrm{Q}=4.2$ (Kotiranta 7411 \& Mannerkoski), $\mathrm{n}=30$, thin-walled, $\mathrm{CB}+$, IKI-.

$B$. intertextum is widely distributed, but nowhere common. The northernmost collections in Sweden and Finland are close to the Polar circle (Eriksson 1958b, Eriksson \& Strid 1969). In Fennoscandia $B$. intertextum seems to prefer coniferous wood in old spruce-dominated forests (Eriksson 1958b, Hjortstam 1973), and reports from angiosperms in deciduous forests are few (Eriksson 1958b, Strid 1975a). The species is known from many European countries, e.g. Czechoslovakia, Norway, Poland (Eriksson 1958b), France (Boidin 1957), the Soviet Union (Parmasto 1965, 1968) and Spain (Hjortstam et al. 1981), where it grows on Quercus robur, Fraxinus excelsior and Pinus radiata (Dueñas \& Tellería 1988). It has been reported outside Europe from the United States (Eriksson 1958b).

\section{Specimens examined}

Finland. Uusimaa: Helsinki, Myllypuro-Puotinharju, decorticated, soft, cut Salix caprea in mixed grass-herb forest, Grid 27E 6680:392, 3.IX.1989 Saarenoksa 18689 (H). Etelä-Häme: Ruovesi, Keinumäki E, Musturi State Forest Reserve, very strongly decayed moss-covered Pinus sylvestris on the ground in mixed virgin Picea abies-Vaccinium myrtillus forest, Grid $27^{\circ} \mathrm{E}$ 6865:362, 14.VI.1989 Kotiranta 7411 \& Mannerkoski (H.K.). Tammela, Liesjärvi Nat. Park, Korteniemi, corticated, mosscovered Picea abies on the ground in mixed spruce-Vaccinium myrtillus forest, Grid $27^{\circ} \mathrm{E}$ 6731:330, 22.X.1983 Kotiranta 5243 (H.K.).

\section{Ceratobasidium pseudocornigerum M.P. Christ. - Fig. 3.}

New to Finland. Fruit body resupinate, hypochnoid - almost corneous, in the beginning very thin translucent, later thicker, dull brownish grey.

Hyphal system monomitic, hyphae simple septate throughout. Basal hyphae with thickened walls, branches ramified at right angles, (6-)7.5-9 $\mu \mathrm{m}$ wide. Subicular and subhymenial hyphae thin-walled, slightly narrower, with few droplets in $\mathrm{KOH}$. Cystidia none. Basidia terminal, very rarely pleural (young?), more or less obovate, basally simple septate (11-)13-16 × 9-9.5 $\mu \mathrm{m}$, with four 11-14 $\mu \mathrm{m}$ long sturdy sterigmata. Spores cylindrical-oblong, sometimes slightly curved, often attached in pairstetrads, 8.6-14.0 × 3.0-4.2 $\mu \mathrm{m}, \mathrm{L}=11.1, \mathrm{~W}=3.8, \mathrm{Q}$ $=2.5-3.7, \bar{Q}=2.9$ (Saarenoksa 04689), $\mathrm{n}=30 ; 7.7-$ $11.0 \times 3.0-4.2 \mu \mathrm{m}, \mathrm{L}=10.0, \mathrm{~W}=3.8, \mathrm{Q}=2.2-3.0, \bar{Q}$ $=2.6$ (Saarenoksa 11389), $\mathrm{n}=30$, repetitive by an apical sterigma, thin-walled, CB-, IKI-.

Our specimens do not fit exactly with the descriptions given by Christiansen (1959) and Eriksson and Ryvarden (1973). The spores in the Finnish collections are of the same size and shape, but the sterigmata of the spores are mostly apical, as in the drawing of Breitenbach and Kränzlin (1986). Only two laterally placed sterigmata were found, and one basal, which arose just beneath the apiculus. The drawing in Eriksson and Ryvarden (1973) of C. stridii Erikss. \& Ryv. fits fairly well with our specimens, but the spores are differently shaped, and the basidia too small. The spores of $C$. anceps (Bres. \& Syd.) Jacks. are also differently shaped and too wide, viz. 4.5-7 $\mu \mathrm{m}$ (Jackson 1949).

C. pseudocornigerum seems to be a rare species, reported from Denmark (Christiansen 1959), Sweden (Eriksson \& Ryvarden 1973, Hjortstam 1979) and Switzerland (Breitenbach \& Kränzlin 1986). Its growth sites are luxuriant and the collections come from deciduous trees, such as Fraxinus and Fagus (Christiansen 1959). 


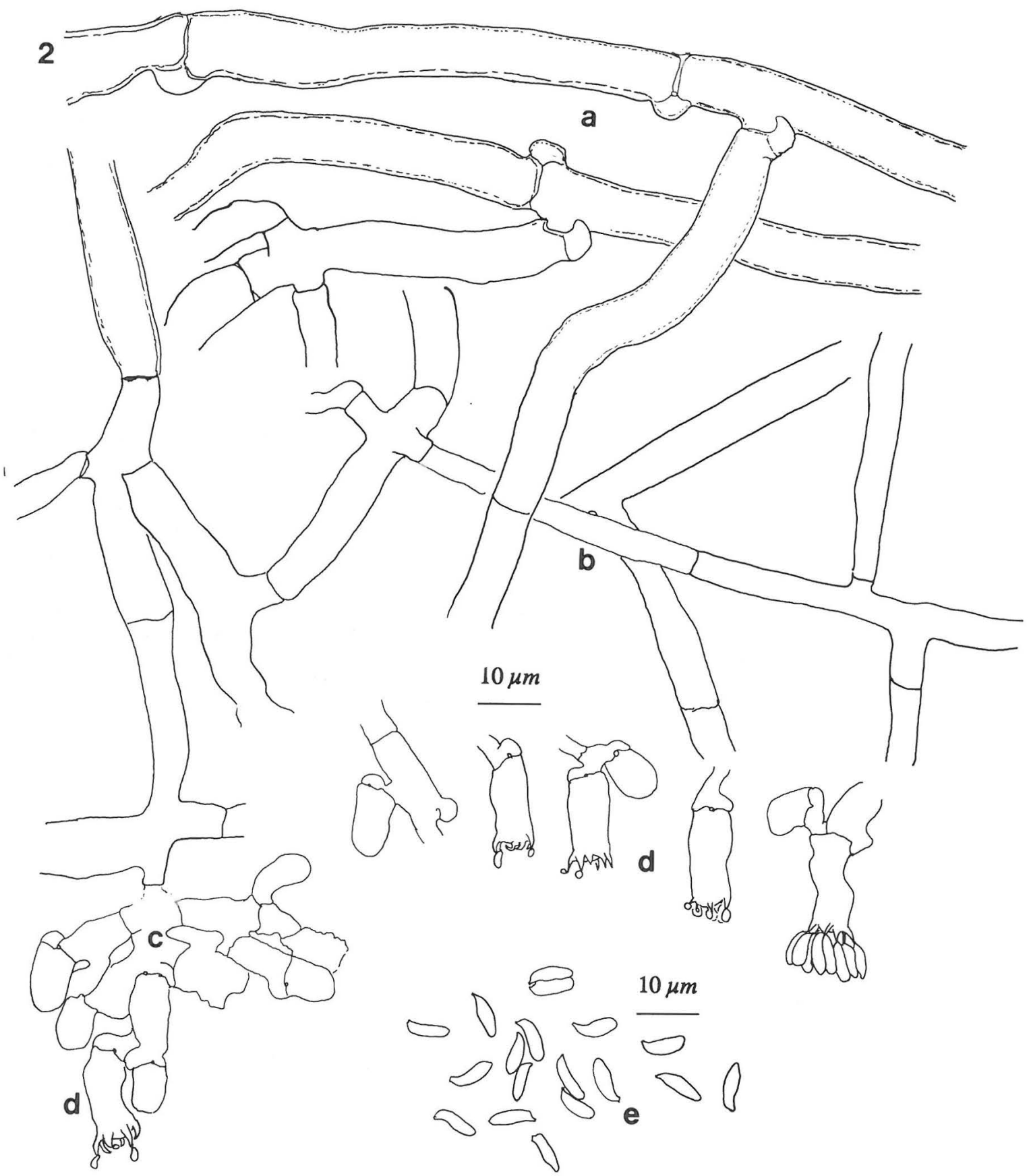

Fig. 2. Botryobasidium intertextum (Schw.) Jül. \& Stalpers. a) clamped basal hyphae, b) simple septate subicular hyphae, c) clamped subhymenial hyphae, d) basidia, e) spores (specimen Kotiranta 7411 \& Mannerkoski, H.K., in KOH).

\section{Specimens examined}

Finland. Uusimaa: Helsinki, Viikki (Wiik), on small twigs of deciduous trees, dead Aegopodium podagraria and dead Filipendula ulmaria in deciduous grass-herb forest intermixed with a few spruces, Grid $27^{\circ} \mathrm{E}$ 6682:391, 7.VI.1989 Saarenoksa 04689 (H, H.K.). Helsinki, Viikki, Hakala, at bases of living Pteridium aquilinium in mixed grass-herb forest, Grid $27^{\circ} \mathrm{E}$ 6680:389, 14.VI.1989 Saarenoksa $11389(\mathrm{H})$. 


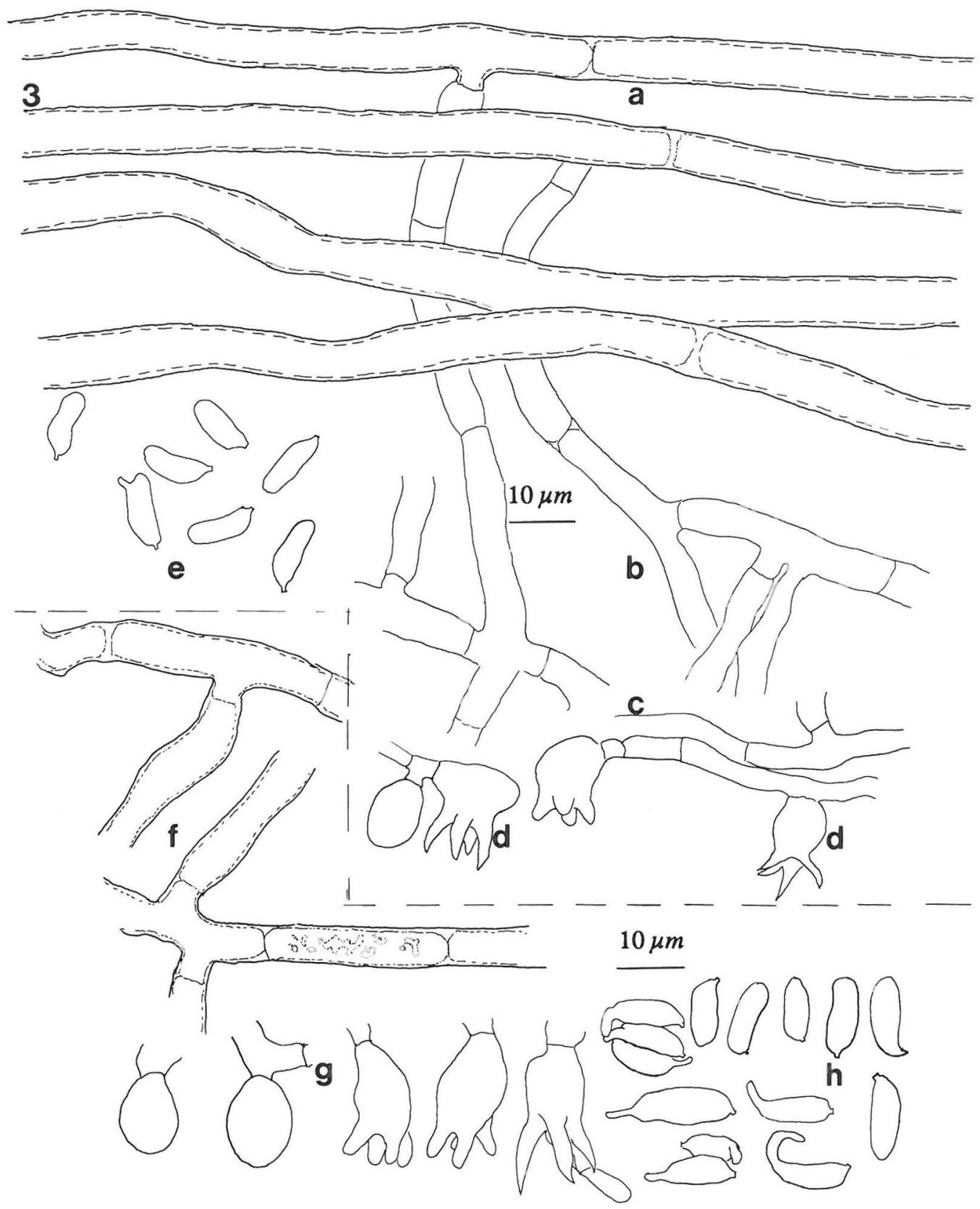

Fig. 3. Ceratobasidium pseudocornigerum M.P. Christ. a) basal hyphae, b) subicular hyphae, c) subhymenial hyphae, d) basidia, e) spores (specimen Saarenoksa 11389, H, in $\mathrm{KOH}$ ).

Confertobasidium olivaceoalbum (Bourd. \& Galz.) Jül. - Fig. 4.

New to Finland. Fruit body resupinate, pellicular, pale cream-coloured, with a few, small, golden brown patches, soft, cracked when dry, loosely attached to the substrate, subiculum light brown, rhizomorphs light creamy brownish.

Hyphal system monomitic. Basal hyphae and hyphae in strands mostly narrow, 2.0-3.0, in a few 


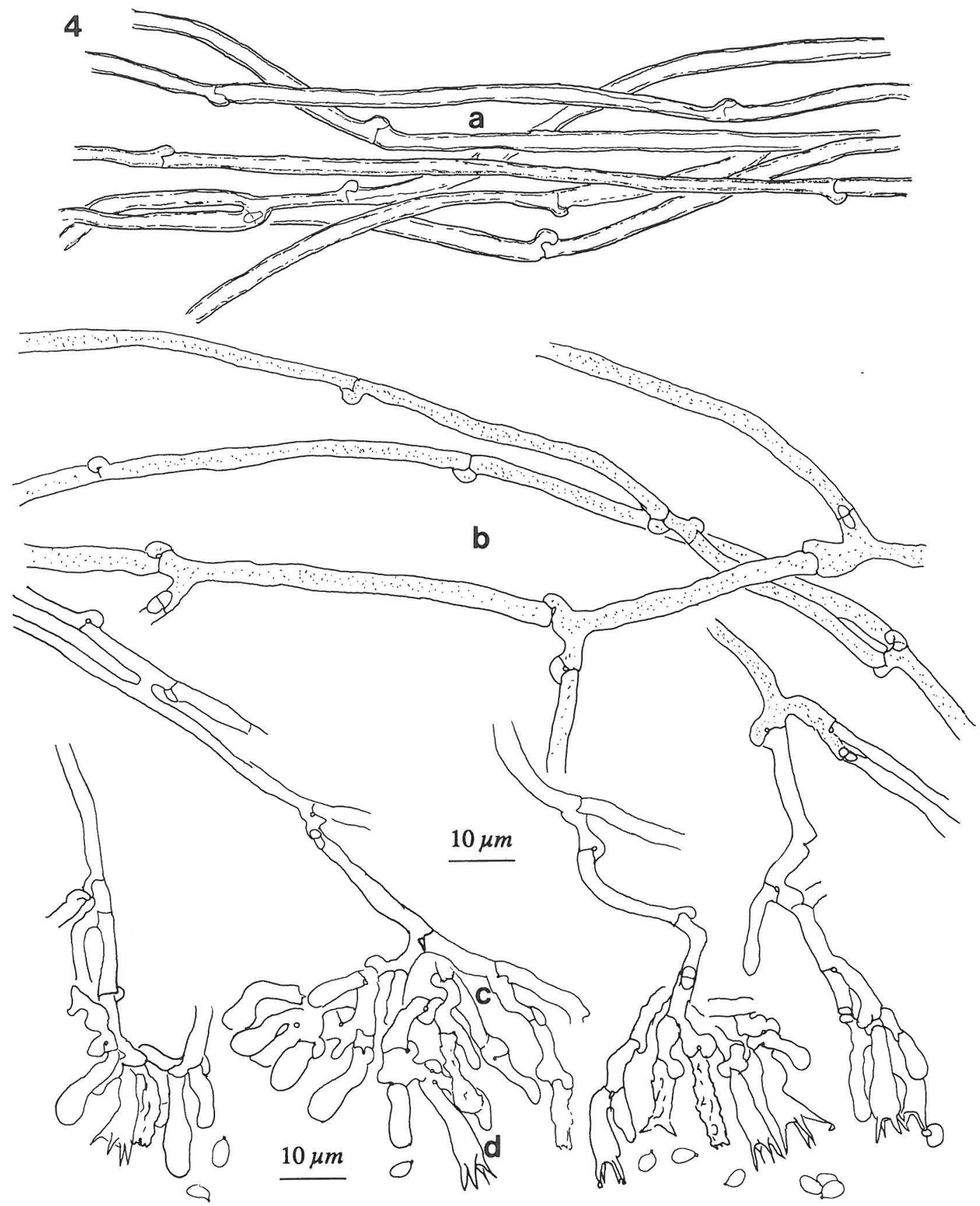

Fig. 4. Confertobasidium olivaceoalbum (Bourd. \& Galz.) Jül. a) pigmented basal hyphae, b) subicular hyphae, c) subhymenium, d) hymenium with basidia and spores (specimen Kotiranta 7388, H, H.K., in KOH).

cases up to $5.0 \mu \mathrm{m}$ wide, sparingly septate with clamp connections, cells $75-125 \mu \mathrm{m}$ long, more or less parallel, with slightly thickened walls, slightly encrusted, golden brown in $\mathrm{KOH}$. Subicular hyphae fairly sparingly septate with clamp connections, 2.5 $3.2 \mu \mathrm{m}$ wide. Subhymenial hyphae richly branched, clamped, thin-walled. Cystidia none. Basidia narrow, clavate, occasionally constricted, (11-)13-15(-17) x 
(3.5-)4-5 $\mu \mathrm{m}$, basally clamped, with four, up to $5 \mu \mathrm{m}$ long sterigmata. Spores subcylindical, $3.2-4.3 \times$ 1.6-2.5 $\mu \mathrm{m}, \mathrm{L}=3.8, \overline{\mathrm{W}}=2.0, \mathrm{Q}=1.4-2.1, \overline{\mathrm{Q}}=1.9$ (Kotiranta 7388), $\mathrm{n}=30$, thin-walled, CB-, IKI-.

Leptosporomyces luteofibrillosus Hjortst. \& Ryv. resembles our specimen, but according to Hjortstam and Ryvarden (1985), the yellow rhizomorphs in the former species should be a good character separating $C$. olivaceoalbum from $L$. luteofibrillosus.

Jülich and Stalpers (1980) consider C. olivaceoalbum a common species and it is reported from several European countries, e.g. Sweden (Strid 1972-73, Eriksson \& Ryvarden 1973), Czechoslovakia, Italy, France, Portugal, Turkey (Jülich 1972), Austria (Jülich 1972, Hallenberg \& Michelitsch 1983), Germany (Kreisel 1987), Switzerland (Breitenbach \& Kränzlin 1986), and outside Europe from the Asian part of the Soviet Union, the United States (Jülich 1972) and Canada (Jülich 1972, Hallenberg 1985).

C. olivaceoalbum prefers all kinds of coniferous wood, and is only seldom collected from angiosperms or from mosses and herbaceous substrates such as ferns (Jülich 1972).

\section{Specimen examined}

Finland. Etelä-Häme: Ruovesi, Siikakangas, on strongly decayed, brown-rotted, dry Pinus sylvestris in open, sunny Cladonia-Pinus contorta (cult.) forest, Grid $27^{\circ} \mathrm{E}$ 6862:357, 13.VI.1989 Kotiranta 7388 (H, H.K.).

Hyphoderma obtusum J. Erikss. - Fig. 5.

Reported earlier by Eriksson \& Strid (1969). Fruit body resupinate, small, thin, at first pale, later greyish pink, also in fresh state.

Hyphal system monomitic, hyphae richly branched, thin-walled, clamped, 3.2-4.0 $\mu \mathrm{m}$ wide. Cystidia thin-walled, clavate, sometimes sinuous, obtuse, $(\mathrm{KOH}), 43-57 \times 8.5-12 \mu \mathrm{m}$. Basidia subclavate $(25-) 33-37(-53) \times(6.0-) 7-8 \mu \mathrm{m}$, basally clamped, with four 8-10 $\mu \mathrm{m}$ long, stout sterigmata. Spores hyaline, ellipsoid, 7.7-13.0 $\times 5.1-8.5 \mu \mathrm{m}, \mathrm{L}=$ $9.4, \mathbb{W}=6.1, Q=1.3-1.9, \bar{Q}=1.5$ (Kotiranta 7731 ), $\mathrm{n}=30$.

H. obtusum is a rare species, only seldom collected outside the Nordic countries: Norway (Eriksson \& Ryvarden 1975), Finland (Eriksson \& Strid 1969) and Sweden (Eriksson 1958a). It has, however, been reported from the Soviet Union (Jülich \& Stalpers 1980) and Spain (Tellería \& Truchero 1981, Dueñas \& Tellería 1985). The Fennoscandian records are from northern parts of the countries, from undisturbed virgin forests. The hosts are Picea abies and Pinus sylvestris.

\section{Specimens examined}

Finland. Perä-Pohjanmaa: Rovaniemi rural comm., Pisavaara Strict Nat. Reserve, on fallen trunk of Picea abies, in virgin spruce-dominated Dryopteris-Vaccinium myrtillus forest, Grid $27^{\circ} \mathrm{E} 735: 41,28$.VIII.1960 Kujala \& Eriksson 9418 (GB). Inarin Lappi: Inari, Nurkkavaara W, Sarmikuusikot E, on decorticated Pinus sylvestris branch on the ground in mixed $P i$ nus-Picea abies ssp. obovata-Betula forest, with undergrowth of Empetrum nigrum ssp. hermaphroditum, Vaccinium uliginosum, V. myrtillus, Ledum palustre, Geranium sylvaticum, Grid $27^{\circ}$ E 7618-9:559, 31.VIII.1989 Kotiranta 7731 (H.K.).

\section{Hyphoderma roseocremeum (Bres.) Donk -}

Fig. 6.

Reported earlier from Finland by Hjortstam (1984). Fruit body resupinate, smooth, fairly thick, not or only partly cracked, at first light creamy, later pale yellowish ochre, with lighter, thinning margin.

Hyphal system monomitic, hyphae richly branched, 3-4 $\mu \mathrm{m}$ wide, thin-walled, amyloid. Cystidia submerged or slightly projecting, tubular, sometimes with a simple septum near the apical end, $57-110 \times 6-8(-9.5) \mu \mathrm{m}$, thin-walled, amyloid. Basidia subclavate, $28-40(-47) \times 5-7 \mu \mathrm{m}$, basally clamped, with four sterigmata, amyloid. Spores cylindrical, 7.0-13.0 $\times 3.7-5.0 \mu \mathrm{m}, \mathrm{L}=9.3, \overline{\mathrm{W}}=4.1, \mathrm{Q}$ $=1.7-3, \bar{Q}=2.3$ (Saarenoksa 29089), $\mathrm{n}=45$, normally with one large droplet, $\mathrm{CB}-$, IKI-.

Our specimen differs from the description given by Eriksson and Ryvarden (1975). There are, however, notes of two specimens which deviate from the general species concept, i.e. 17.X.1965 K. Hauerslev, which has amyloid hyphal walls in the context, and 21.X.1973 Jeppson (p. 524), which has sparser cystidia and broader spores. Our specimen has slightly broader spores than those mentioned and illustrated by Eriksson and Ryvarden (1975: 522-523), but they fit well with the drawing on page 524. In addition, our specimen has fairly many cystidia and both the subicular hyphae and the basidia are amyloid.

H. medioburiense (Burt) Donk, which is surely a close relative, has dark dots on the hymenium, and longer spores, $12 \mu \mathrm{m}$ or more (Eriksson \& Ryvarden 1975). We have studied one collection of $H$. medioburiense (Sweden. Västergötland: Göteborg, Backplan, on dead trunk of coniferous tree, 17.VIII.1946 T. Nathorst-Windahl, GB). It is light rose-coloured, has long spores and an inamyloid context, but almost entirely lacks brown dots on the hymenium.

$H$. roseocremeum seems to be common elsewhere, and its distribution is southern (Strid 1975a). It has been reported, from Denmark (Christiansen 1960), Sweden (Eriksson 1948, Hjortstam 1973, 1979b, Strid 1975a, Hallenberg \& Sunhede 1979), 


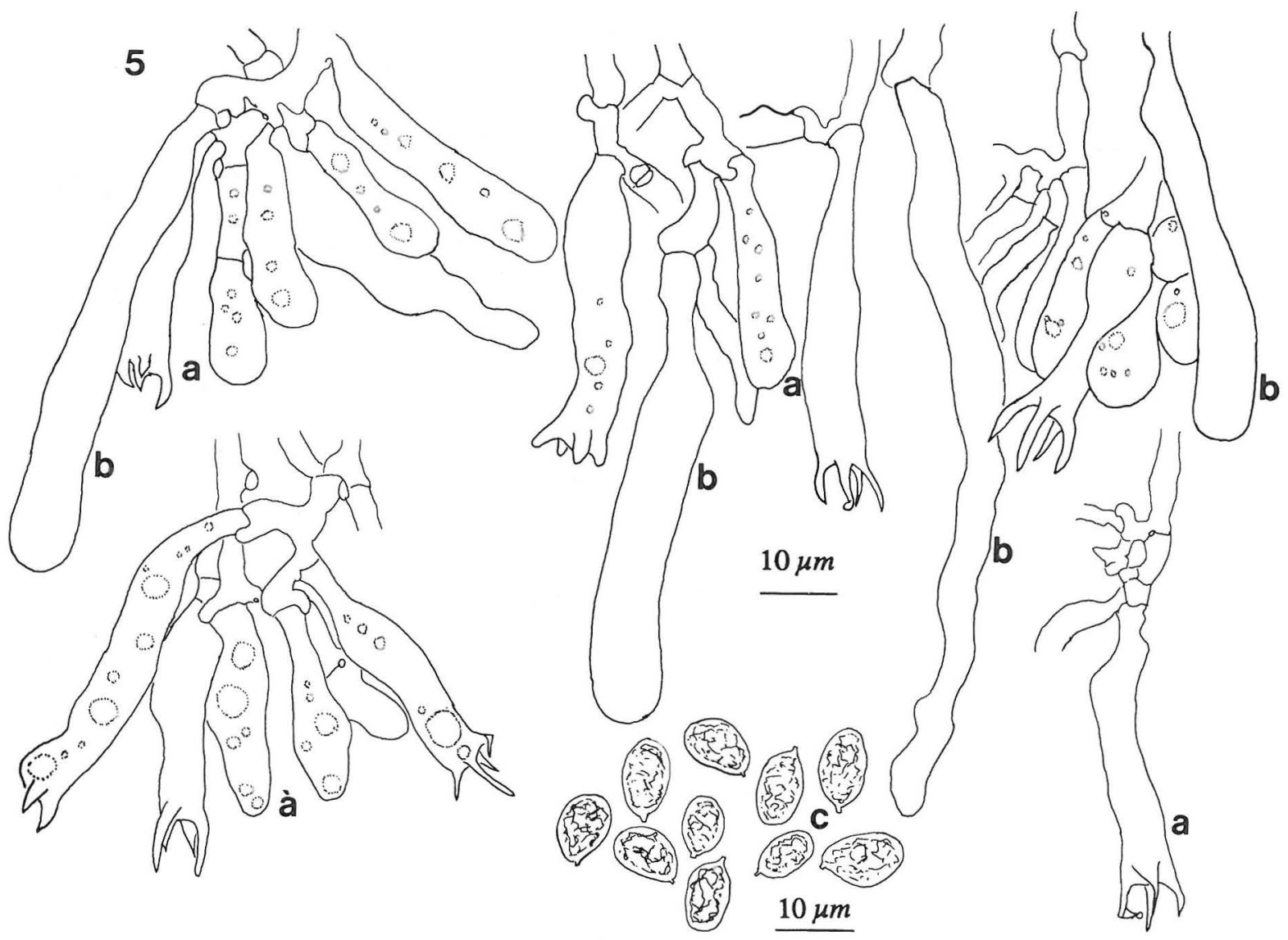

Fig. 5. Hyphoderma obtusum J. Erikss. a) basidia, b) cystidia, c) spores (specimen Kotiranta 7731, H.K., in KOH).

Germany (Doll 1979), Austria (Hallenberg \& Michelitsch 1982-83), Great Britain (Scotland; Hallenberg 1984a), Spain (Hjortstam \& al. 1981, Dueñas \& Tellería 1988), France (Jülich 1984) and outside Europe from Iran (Hallenberg 1981), Argentina (Hjortstam \& Ryvardean 1985) and Canada (Liberta 1966, Hallenberg 1984a).

$H$. roseocremeum grows almost exclusively on deciduous trees, and reports from softwood come mainly from Canada (Liberta 1966, Hallenberg 1984a).

\section{Specimen examined}

Finland. Uusimaa: Vantaa, Tammisto, on fallen, corticated Corylus avellana and dead fruit bodies of the polypore?Phellinus punctatus (Karst.) Pil. (ster.) in mixed grass-herb forest, Grid $27^{\circ}$ E 6686:387, 24.IX.1989 Saarenoksa 29089 (H, H.K.).
Hyphodontia alienata (Lund.) J. Erikss. — Fig. 7.

Reported earlier from Finland by Eriksson and Ryvarden (1976). Fruit body resupinate, fairly thin, soft, almost smooth to the naked eye, under the lens papillose, floccose, tomentose due to the projecting cystidia, margin thinning out, pale ochre.

Hyphal system monomitic, all hyphae clamped, IKI-. Basal and subicular hyphae richly branched, with thickened walls, $3.5-4.5 \mu \mathrm{m}$ wide, subhymenial ones richly clamped, with thinner walls, but of the same width. Cystidia fusiform, 98-150 x 5.5$9.0 \mu \mathrm{m}$, often encrusted in the middle part when viewed in $\mathrm{CB}$ and IKI, smooth in $\mathrm{KOH}$, sometimes with short and bulbous side branches, thick-walled, except for the apical end, CB+, IKI-. Basidia subcylindrical, $21-26 \times 4.5-5 \mu \mathrm{m}$, basally clamped, with 


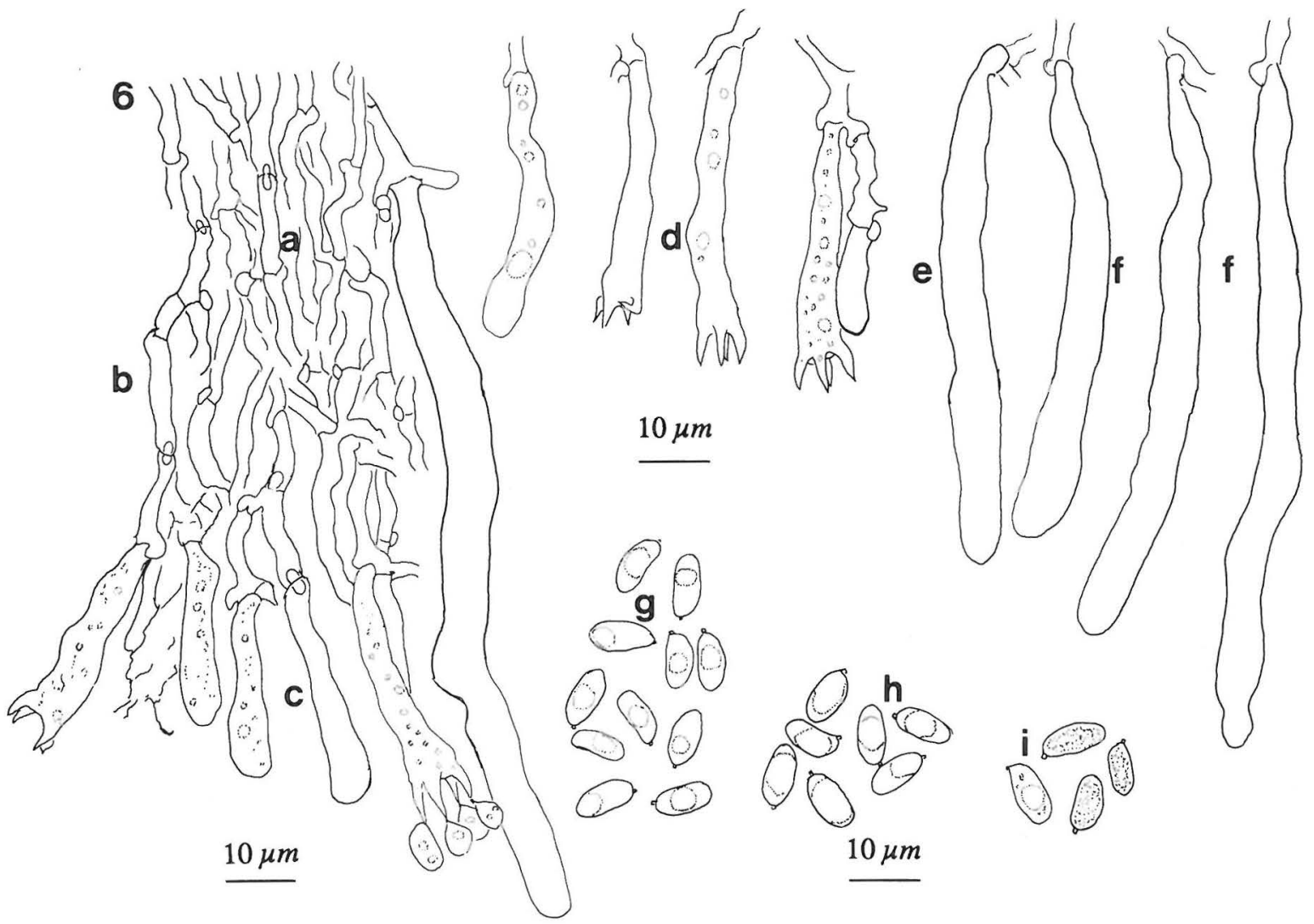

Fig. 6. Hyphoderma roseocremeum (Bres.) Donk. a) vertical section through fruit body in $\mathrm{KOH}, \mathrm{b}$ ) context, c) hymenium, d) basidia in $\mathrm{CB}, \mathrm{e}$ ) cystidia in $\mathrm{CB}, \mathrm{f}$ ) cystidia in $\mathrm{KOH}, \mathrm{g}$ ) spores in CB, h) spores in IKI, i) spores in KOH (specimen Saarenoksa 29089, H, H.K.).

four sterigmata. Spores ellipsoid, smooth, adaxial side straight or slightly concave, abaxial side convex, 4.9-5.9 x 2.8-3.5 $\mu \mathrm{m}, \mathrm{L}=5.4, \mathrm{~W}=3.0, \mathrm{Q}=$ $1.5-2.0, \bar{Q}=1.8$ (Kotiranta 7555), $\mathrm{n}=30, \mathrm{CB}-$, IKI-

$H$. alienata is a rare species, reported from Sweden, Poland, Czechoslovakia (Eriksson \& Ryvarden 1976), Germany (Doll 1979) and Canada (Liberta 1966, Martin \& Gilbertson 1977). The spore size mentioned by Martin and Gilbertson (1977) is greater than the European measurements: $6-7.5 \times 4-4.5 \mu \mathrm{m}$. In addition, the cystidia in the Canadian material are smooth.

The growth sites are usually luxuriant, and the hosts are mainly deciduous trees.

\section{Specimen examined}

Finland. Kittilän Lappi: Kittila, Homevuotso State Nature Reserve, on wet, fallen Betula sp. bark in virgin Picea abiesdominated grass-herb forest, Grid $27^{\circ} \mathrm{E}$ 7519:398-9, 28.VIII.1989 Kotiranta 7555 (H, H.K.).

\section{Hyphodontiella multiseptata Strid}

Finland. Etelä-Häme: Luhanka, Lempäă, Leppäjoki W parts, on strongly decayed Prunus padus on the ground, in broadleaved (Alnus glutinosa, Populus tremula, Betula, Tilia cordata) brook-side grass-herb forest, Grid $27^{\circ} \mathrm{E}$ 68496:4337-8, 29.IX.1989 Kotiranta 7902 (H.K.). Perä-Pohjanmaa: Rovaniemi rural comm., Pisavaara Strict Nat. Res., Sorvannulikka, $\mathrm{N}$ slope, on dead fern, together with Tylospora asterophora (Bon.) Donk and T. fibrillosa (Burt) Donk, also on wet piece of Populus tremula in virgin, fairly luxuriant, spruce-dominated forest, Grid $27^{\circ} \mathrm{E} 735: 41$, 6.IX.1989 Kotiranta $7814 b(\mathrm{H}), 7815$ (H.K.).

For the other collections from Finland, see Kotiranta and Larsson (1990).

\section{Hypochniciellum cremeoisabellinum (Litsch.)} Hjortst. - Fig. 8.

Reported earlier from Finland by Hjortstam (1984). Fruit body resupinate, at first hypochnoid, later pellicular, resembling very thin paper, smooth, white 


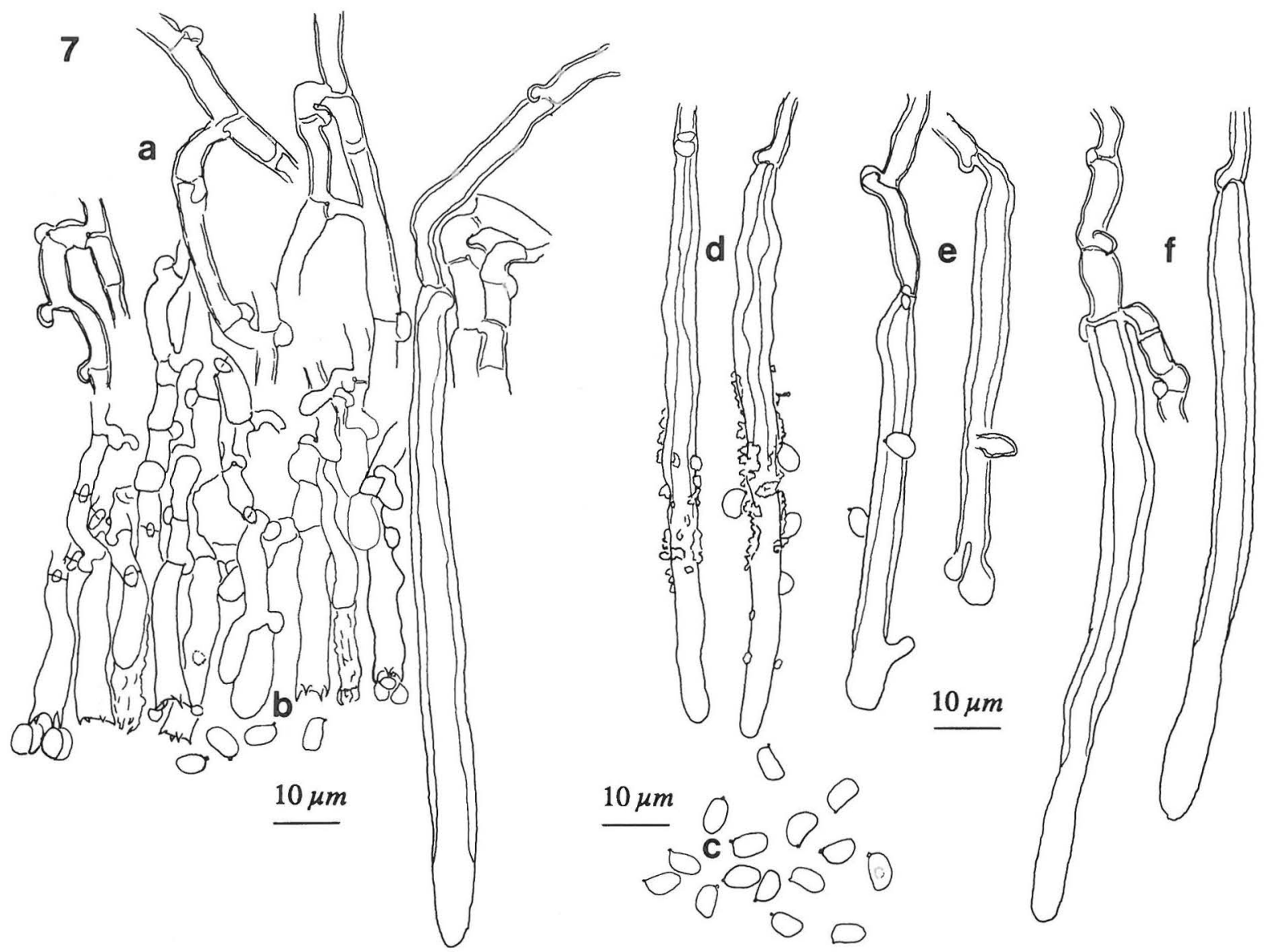

Fig. 7. Hyphodontia alienata (Lund.) J. Erikss. a) section through fruit body in $\mathrm{CB}, \mathrm{b}$ ) basidia with spores, c) spores in $\mathrm{KOH}, \mathrm{d}$ ) cystidia in CB, e) cystidia in IKI, f) cystidia in $\mathrm{KOH}$ (specimen Kotiranta 7555, H, H.K.).

when fresh, turning slightly cream-brown when dry, easily detachable, margin even, porose-reticulate under lens.

Hyphal system monomitic, all hyphae clamped, thin-walled, CB-, IKI-, collapsing easily in CB. Cystidia none. Basidia clavate, sometimes constricted, $(15-) 20-27(-30) \times(4.8-) 5.0-5.5 \mu \mathrm{m}$, basally clamped, with four, up to $5 \mu \mathrm{m}$ long sterigmata. Spores ellipsoid, adaxial side straight or slightly convex, abaxial side concave, 4.9-6.0 x 3.0-3.7 $\mu \mathrm{m}$, $\mathrm{L}=5.4, \overline{\mathrm{W}}=3.2, \mathrm{Q}=1.5-1.9, \overline{\mathrm{Q}}=1.6$ (Saarenoksa $41488), \mathrm{n}=30$, with small apiculus, thickened walls, $\mathrm{CB}+$, IKI+ (faint greyish hue).

The greyish reaction of the spores is mentioned by Eriksson and Ryvarden (1976) and Hjortstam (1981), but not, by some other authors, e.g. Jülich and Stalpers (1980) and Jülich (1984). In the Finnish material the reaction varies from specimen to specimen. In
Saarenoksa 41488, the spores are grey in IKI, and in 17.X.1979 Fagerström only some spores become stained.

H. cremeoisabellinum is nowhere common, but is reported from Sweden (Eriksson \& Ryvarden 1976, Hjortstam 1981), Norway (Hjortstam 1981, Aanstad \& Ryvarden 1987), Spain (Dueñas \& Tellería 1984), the Soviet Union (Parmasto 1967, as Athelia subtessulata Parm., see Jülich \& Stalpers 1980) and Argentina (Hjortstam \& Ryvarden 1985).

$H$. cremeoisabellinum grows mostly on conifers, but also on hardwood, dead herbs and mosses.

\section{Specimens examined}

Finland. Uusimaa: Helsinki, Vanhakaupunki, Annala, on dead mosses, peat, litter and soil on open rock, Grid $27^{\circ} \mathrm{E}$ 6679:387, 12.X.1988 Saarenoksa 41488 (H, H.K.). Etelä-Karjala: Vehka- 
lahti, Pyhältō, Sirkkamäki, on corticated Picea abies in spruce-dominated forest, Grid $27^{\circ} \mathrm{E}$ 673:51, 17.X.1979 Fagerström $(\mathrm{H})$.

Hypochnicium erikssonii Hallenb. \& Hjortst. - Fig. 9.

Hypochnicium sphaerosporum (v. Hohn. \& Litsch.) J. Erikss. sensu Eriksson \& Ryvarden. The Corticiaceae of North Europe 4:727-729 (1976).

New to Finland. Fruit body resupinate, at first thin, hypochnoid, later thicker, subceraceous, almost smooth to the naked eye, with small granules, porose under the lens, margin not differentiated, thinning out, pale cream to light ochre.

Hyphal system monomitic, all hyphae clamped, 4-5 $\mu \mathrm{m}$ wide, richly branched, thin-walled, $\mathrm{CB}+$. Cystidia tubular or clavate or sinuous, sometimes even more or less moniliform, in a few cases bifurcate, $(60-) 80-131 \times(7-) 9-12 \mu \mathrm{m}$. Basidia subclavate, often constricted, (27-)30-37 x (5-)6-7.5 $\mathrm{m}$, basally clamped, with four sterigmata. Spores subglobose, 5.2-7.2 x 4.5-6.1, $\mathrm{L}=6.7, \mathrm{~W}=5.7, \mathrm{Q}=1.1-1.3$, $\bar{Q}=1.2$ (Saarenoksa 29389), $\mathrm{n}=30$, with small apiculus, with one droplet, smooth, thick-walled, $\mathrm{CB}+$, IKI-, slightly swelling in $\mathrm{KOH}$ (measurements made in $\mathrm{CB}$ ).

The distribution of $H$. erikssonii is not clear, because $H$. subrigescens Boid. (see below) may be included in this taxon. $H$. erikssonii, however, has been reported from Sweden (Eriksson \& Ryvarden 1976), Spain (Dueñas \& Tellería 1988) and Tanzania (Hjortstam 1987). The literature on $H$. erikssonii is considerable, and records have been published from at least the following countries: Denmark (Christiansen 1960, spores 5.5-7 $\mu \mathrm{m}$ ), Germany (Doll 1979, Jülich 1984), Austria (Hallenberg \& Michelitsch 1983), Czechoslovakia, France, Norway (Jülich 1984), and the United States (Gilbertson \& Budington 1970, Gilbertson 1974, spores 5-6.5 $\mu \mathrm{m}$ ). H. erikssonii grows on both hard- and softwood.

For the nomenclature see Hallenberg and Hjort$\operatorname{stam}(1990)$.

\section{Specimen examined}

Finland. Uusimaa: Vantaa, Tammisto, on fallen, fairly thin, soft, decorticated Populus tremula, in mixed grass-herb forest, Grid $27^{\circ} \mathrm{E}$ 6686:387, 24.IX.1989 Saarenoksa 29389 (H, H.K.).

Hypochnicium subrigescens Boid. - Fig. 10.

New to Finland. Fruit body resupinate, thin, subpellicular, gelatinous-corneous when fresh, corneous when dry, smooth to the naked eye, finely porose under the lens, margin not differentiated, thinning out, bluish grey when fresh, pale greyish ochre when dry.

Hyphal system monomitic, but in the present specimen in poor condition; firmer than in H. erikssonii (see also Hjortstam 1987). Cystidia 50-100 x 5-10 $\mu \mathrm{m}$, thin-walled, as in H. erikssonii (also bifurcate seen). Hymenium disintegrated, but (according to Hjortstam 1986) basidia, 20-25(-30) x 5-6 $\mu \mathrm{m}$, somewhat constricted, basally clamped, and with four sterigmata. Spores subglobose, $4.2-6.0 \times 3.6-$

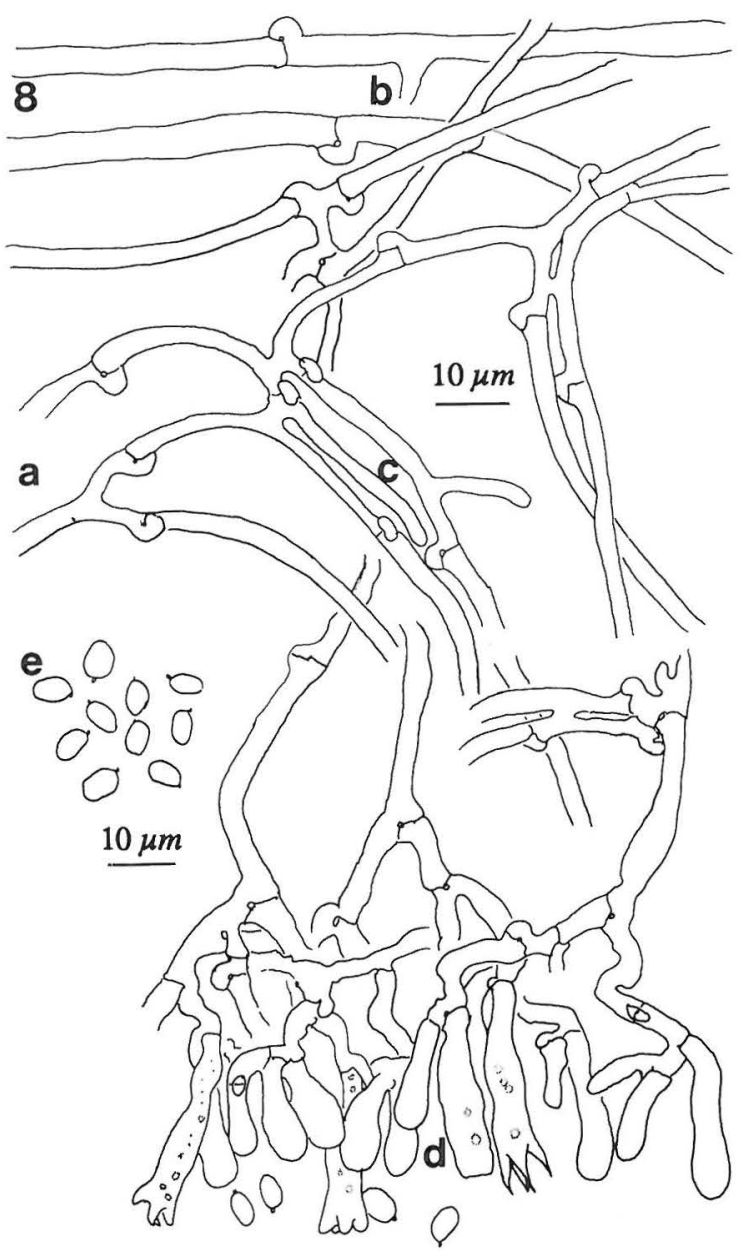

Fig. 8. Hypochniciellum cremeoisabellinum (Litsch.) Hjortst. a) crush preparation of fruit body, b) basal hyphae, c) context hyphae, d) hymenium with basidia and spores, e) spores (specimen Saarenoksa 41488, H, H.K., in IKI). 
$5.0 \mu \mathrm{m}, \overline{\mathrm{L}}=4.7, \mathrm{~W}=4.1, \mathrm{Q}=1.0-1.5, \bar{Q}=1.2$ (25.IX.1937 Laurila), $\mathrm{n}=30$, with a very small apiculus, with one droplet, smooth, thick-walled, $\mathrm{CB}+$, IKI-, swelling in $\mathrm{KOH}$ (measurements made in $\mathrm{CB})$.

The description of the fresh fruit body is according to the hand-written note of M. Laurila in the package.

H. subrigescens seems to be easily separated from $H$. erikssonii, mainly by the firmer hyphal texture and smaller spores, with a negligible apiculus. Moreover, the basidia are smaller, 20-26 × 5-6 $\mu \mathrm{m}$ (Boidin \& Lanquetin 1971, Hjortstam 1986).

H. subrigescens is a rare species, hitherto reported from Sweden, Germany (Hjortstam 1986), Central Africa (Boidin \& Lanquetin 1971), and Kenya (Hjortstam 1986, 1987). Although reported fairly recently from North Europe (Hjortstam 1986), its oc-

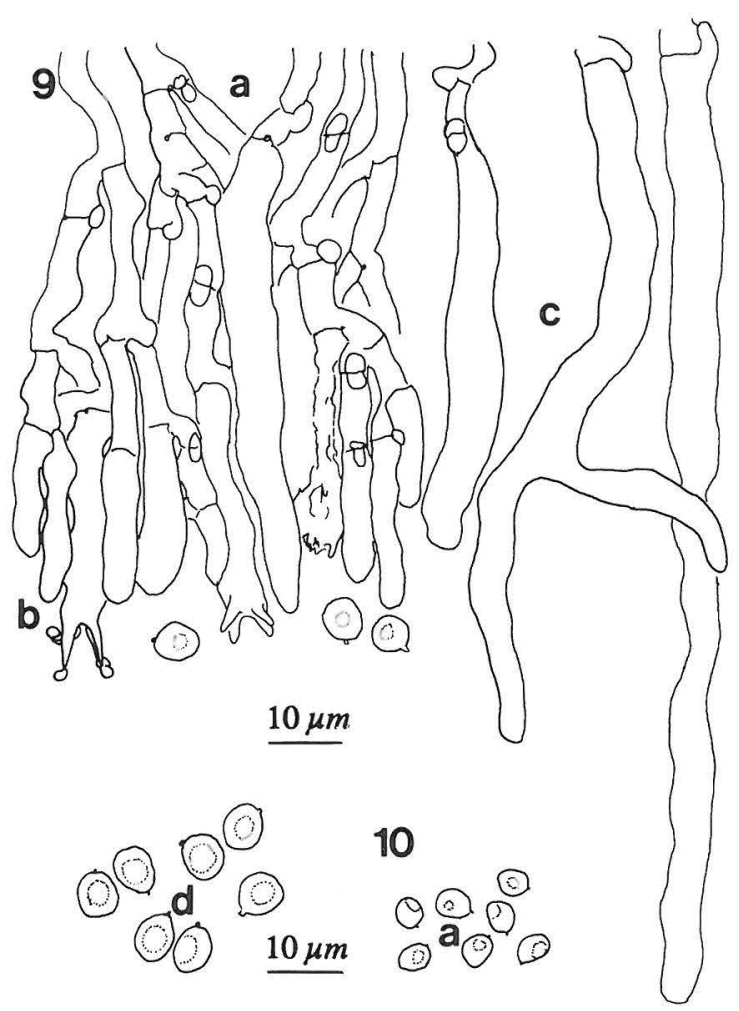

Figs. 9-10. Fig. 9. Hypochnicium erikssonii Hallenb. \& Hjortst. a) section through fruit body in $\mathrm{KOH}$, b) hymenium with basidia, cystidia and spores, c) cystidia in $\mathrm{KOH}$, d) spores in CB (specimen Saarenoksa 29389, H, H.K.). - Fig. 10. Hypochnicium subrigescens Boid. a) spores in CB (specimen Laurila 25.IX.1927, H-LA). currence has been known longer: see Hjortstam (1973: 113) and Eriksson \& Ryvarden (1976).

All but one of the collected specimens are from deciduous trees: Abizzia sp. (Mimosaceae, holotypus), Alnus glutinosa, Betula sp., Populus tremula and Quercus.

\section{Specimen examined}

Finland. Satakunta: Noormarkku, Poosjoki, Entrăskijărvi brook, on very large, corticated, fallen Alnus glutinosa in spruce-hardwood swamp, Grid $27^{\circ} \mathrm{E}$ 6848:225, 25.IX.1937 Laurila (H-LA). This specimen was determined in 1976 by J. Eriksson as "H. subsphaerosporum var.!", and its identity with H. subrigescens was noted by K.-H. Larsson (Göteborg) in 1989.

Jaapia ochroleuca (Bres.) Nannf. \& J. Erikss.

Finland. Inarin Lappi: Inari, Nurkkavaara W, Sarmikuusikot E part, inside a strongly decayed, brown-rotted (?), wet pine trunk in virgin pine-spruce forest, with Empetrum nigrum ssp. hermaphroditum, Vaccinium uliginosum, V. myrtillus, V. vitis-idaea and Ledum palustre, Grid $27^{\circ} \mathrm{E}$ 7618-9:559, 31.VIII.1989 Kotiranta 7717 (H.K.).

Cystidia up to $205 \mu \mathrm{m}$ long, basidia $30-36 \times 7-$ $8 \mu \mathrm{m}$, basally clamped, spores $11.8-15.0 \times 4.8$ $7.0 \mu \mathrm{m}$, strongly dextrinoid.

For the other collections from Finland, see Kotiranta and Larsson (1990).

\section{Kavinia alboviridis (Morgan) Gilbertson \& Budington}

Finland. Kittilän Lappi: Kittilä, Homevuotso State Forest Reserve, on strongly decayed part of fallen Betula sp., together with the polypores Phellinus igniarius (L.) Quél. and P. laevigatus (Fr.) Bourd. \& Galz. and Sistotrema brinkmannii (Bres.) J. Erikss. in virgin Picea abies-dominated grass-herb forest, Grid $27^{\circ}$ E 7519:398-9, 27.VIII.1989 Kotiranta $7532(\mathrm{H})$.

For the other collections from Finland, see Kotiranta and Larsson (1990).

Litschauerella clematitis (Bourd. \& Galz.) J. Erikss. \& Ryv. - Fig. 11.

New to Finland. Fruit body resupinate, fairly thick, up to $0.2 \mathrm{~mm}$, smooth to the naked eye, hispid under the lens, light cream-coloured with brownish tint, margin not differentiated, clear, abrupt.

Hyphal system monomitic, hyphae clamped, hyaline, thin-walled, CB+, IKI-, 1-2 $\mu \mathrm{m}$ wide. Multirooted cystidia numerous, conspicuous, conical, 115$135 \times 11-17 \mu \mathrm{m}$, mostly sharp-pointed, thick-walled, $\mathrm{CB}+$, basal part brown and encrusted in IKI, smooth 

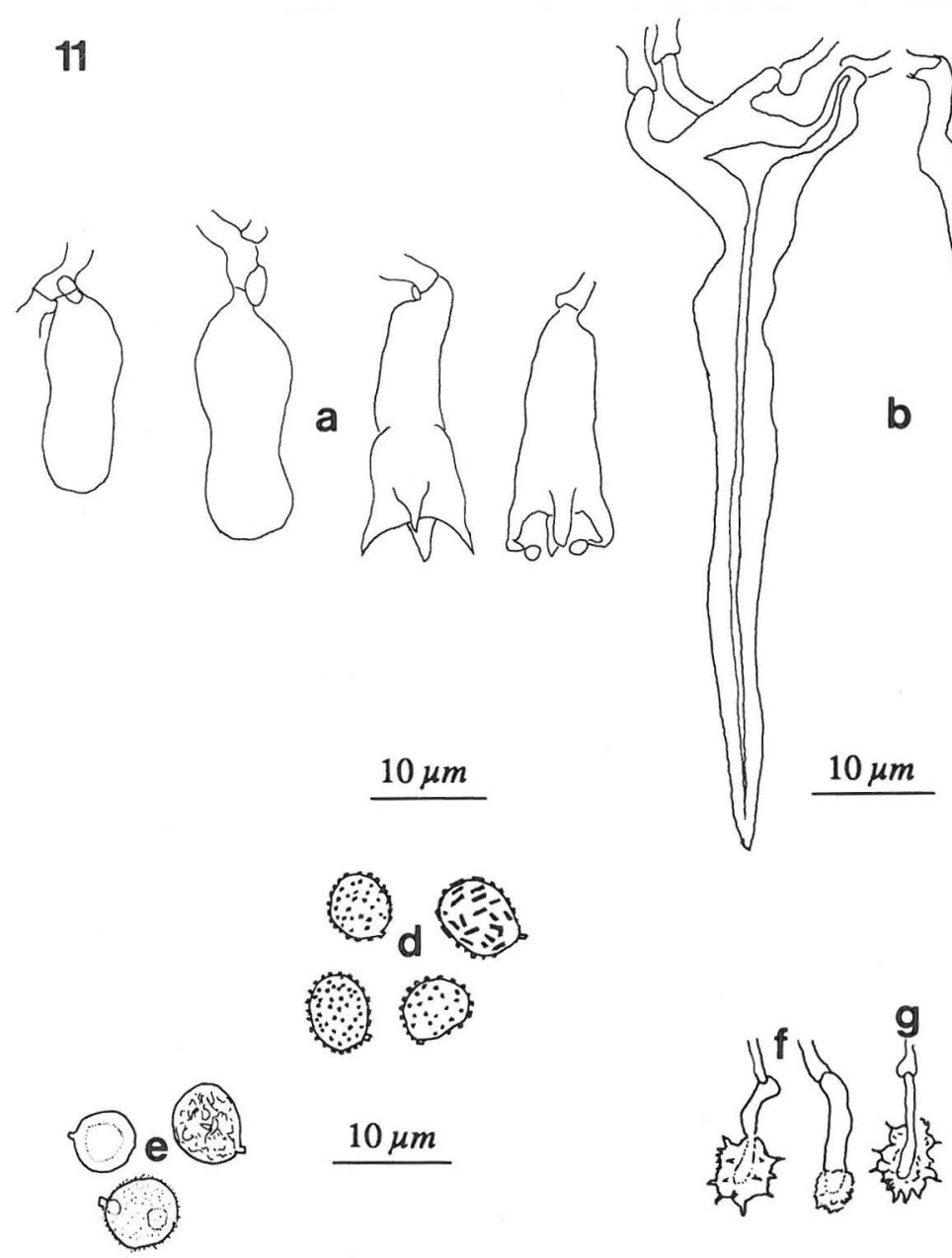

$10 \mu m$
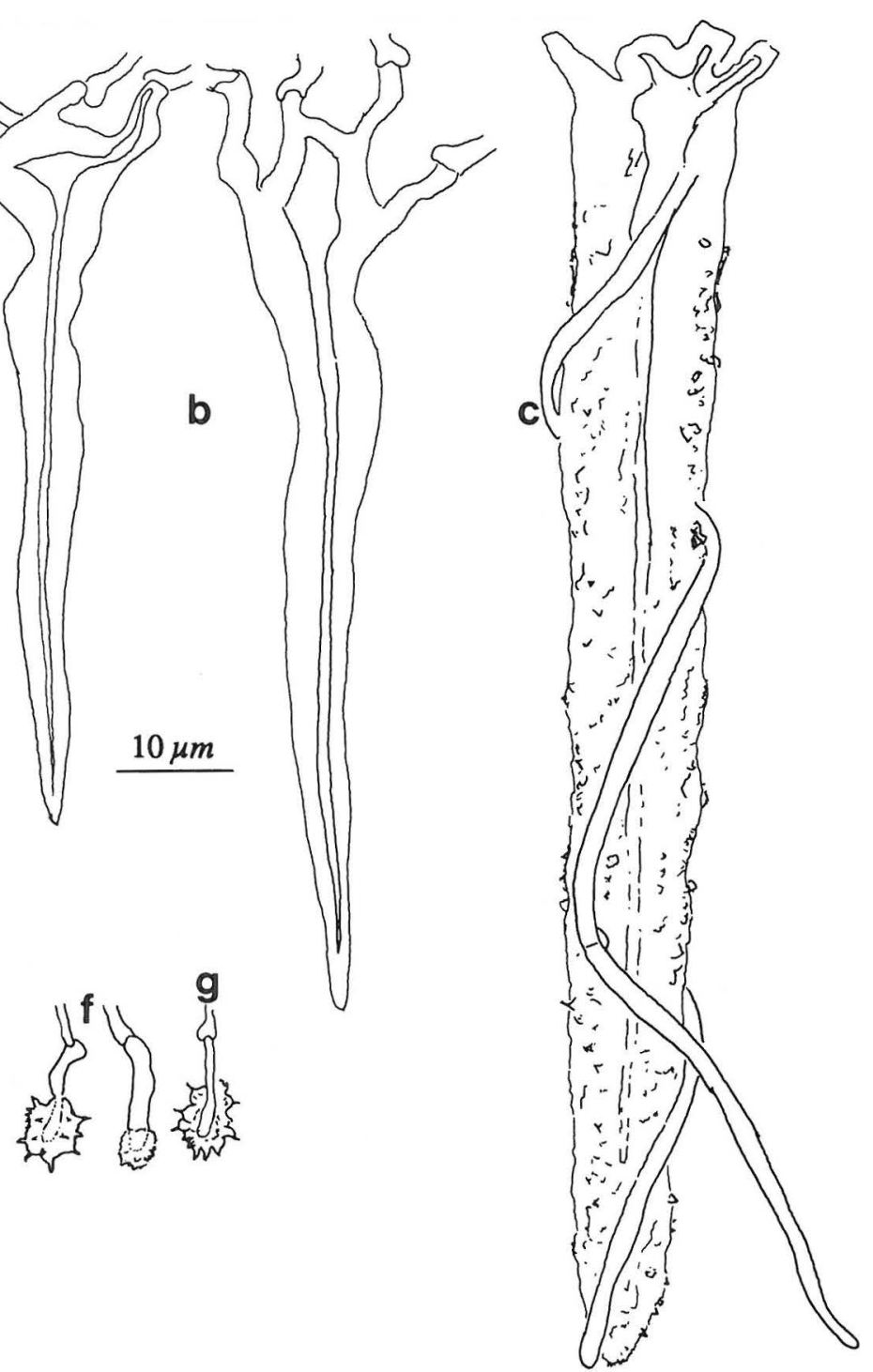

Fig. 11. Litschauerella clematitis (Bourd. \& Galz.) Erikss. \& Ryv. a) basidia in KOH, b) cystidia in CB, c) cystidia in IKI, d) spores in IKI, e) spores in CB, f) paraphysate hyphae, capped with rose-thorn shaped crystals in CB, and g) in IKI (specimen Kotiranta 7511 \& Saarenoksa 13589, H, H.K.).

in $\mathrm{CB}$, occasionally covered with single, clamped, climbing-liane hyphae. Paraphysate hyphae fairly numerous, bearing a cap of acicular crystals, projecting more than $10 \mu \mathrm{m}$, the encrusted part up to $8 \times$ $4 \mu \mathrm{m}$, single crystals acute conical, or sharp-pointed "rose-thorn"-like. Basidia usually terminal, mostly basally encrusted, $16-21 \times 6.5-8 \mu \mathrm{m}$, cylindrical, when immature often constricted, basally clamped, with four, up to $5 \mu \mathrm{m}$ long, basally stout sterigmata. Spores subglobose, $5.0-7.8 \times 4.6-6.3 \mu \mathrm{m}, \mathrm{L}=6.8$, $\widehat{\mathrm{W}}=5.5, \mathrm{Q}=1.1-1.4, \overline{\mathrm{Q}}=1.2$ (Kotiranta $7511 \&$
Saarenoksa 13589) $\mathrm{n}=30$, with a fairly large apiculus, mostly finely warted in IKI, smooth or almost so in $\mathrm{CB}$, smooth in $\mathrm{KOH}, \mathrm{CB}-$ (contents blue), IKI-.

Bourdot and Galzin (1928) describe the basidia and spores of two closely related species as follows: "Peniophora clematitis B. \& G. ... basides 9-12 x 4-4.5 $\mu$, à 2-4 stérigmates longs de 4-4.5 $\mu$; spores subglobuleuses, brièvement apiculées à la base, 4-5x 4-4.5 $\mu$, 1-guttulées." and "Peniophora abietis B. \& G. ... basides $18-21 \times 6-9 \mu \mathrm{m} \ldots$ spores globuleuses, 6-8-11 $\mu$ diam., très finement ruguleuses." 
Thus, it seems, there are two species, which differ from each other in spore shape and size, and in the size of the basidia. However, Weresub (1961) studied both species and Peniophora gladiola Cunningh., and drew the conclusion that the species do not differ microscopically, but represent one taxon only, which "must be called $P$. clematidis" (for the spelling of the epithet see Eriksson \& Ryvarden 1976: 841). Boidin (1958) measured over 5500 spores of L. clematitis and noted that the variation in spore size is great, ranging within a single sample from 4.5 to $16 \mu \mathrm{m}$. This phenomenon is explained by the possibility of polyploidy in L. clematitis (Boidin 1958). Weresub's (1961) opinion was accepted later, e.g. by Liberta (1962), Jülich \& Stalpers (1980) and Jülich (1984). However, Weresub (1961) overlooked the only collection of $P$. abietis mentioned by Boidin and Galzin (1928), viz. that made by L. Corbière = Bourdot 32350 (see Eriksson \& Ryvarden 1976: 841). Eriksson and Ryvarden (1976) studied spores of that specimen under the scanning electron microscope and noted differences in spore ornamentation between it and $P$. clematitis s.str. (Bourdot 15690). They left the Corbière specimen unnamed (Litshauerella sp.) until more material is available. They did not exclude the possibility that Peniophora hastata Cunningh. is identical with it. Weresub (1961) studied the holotype of $P$. hastata and noted the more pronounced projections of the spore wall.

Oberwinkler (1966b) strongly disagreed with Weresub's (1961) solution of synonymizing $P$. abietis with $P$. clematitis, and placed (invalidly, see Jülich 1979: 334-335) the species in separate genera, mainly because of the different basidial morphology. According to Oberwinkler (1966b) the basidia in Litschauerella abietis (Bourd. \& Galz.) Oberw. ex Jül. are pleural and in Tubulicium "clematidis" (Bourd. \& Galz.) Oberw. terminal.

Apart from our collection, we have studied only one specimen of L. clematitis: Sweden. Västergötland, Hjortstam 6648 (GB). That specimen is very thin, white, and finely porose and pilose under the lens. Microscopically, it also differs from our collection: the cystidia are thinner, the basidia clearly pleural, $12 \times 6 \mu \mathrm{m}$, basally not encrusted, the spores globose, smooth or very finely warted, $5-8 \mu \mathrm{m}$ in diam. It also lacks the paraphysate hyphae with crystalline caps.

None of the descriptions given above fits exactly with our material, though the description of Litschauerella sp. (Bourdot 32350) in Eriksson and Ryvarden (1976) comes fairly close. That species has broadly ellipsoid spores (Eriksson \& Ryvarden 1976) of the same size as ours, but the spore ornamentation is different: the warts are small, but clearly larger than in Hjortstam 6648. Surprisingly, in the Finnish specimen there were two spores which had the same ornamentation as Bourdot 32350. Although the spores were not investigated with the SEM, the shape of the warts was visible in IKI mounts studied with the light microscope. Moreover, Eriksson \& Ryvarden claim that the basidia are terminal in Bourdot 32350, like the majority in our collection. Oberwinkler (1966b) described the spores of $L$. abietis as globose and finely warted, and the basidia as pleural. He did not study Bourdot 32350, but puts Peniophora gladiola in the synonymy of L. abietis (like Weresub 1961), which according to Cunningham (1955) is a smooth-spored species. It seems that $P$. gladiola is a synonym of $L$. clematitis.

Cunningham's (1955) drawing of $P$. gladiola shows crystal-capped paraphysoid hyphae similar to those in the Finnish specimen. To us, it seemed that some of the individual crystals had a rose-thorn shape, a character so far reported only from the polypore genus Skeletocutis Pouz. (e.g. Keller 1979, David 1982, Kotiranta 1984). If this is actually the case, it casts doubt on the taxonomic status of these peculiar crystals. Eriksson and Ryvarden (1976) do not mention crystal-capped hyphidia in Litschauerella sp. (Bourdot 32350), nor did Cunningham (1955) or Weresub (1961) observe them in $P$. hastata. The staining of the spores observed by Eriksson (1954) in $P$. abietis was not noted in our specimen.

The Finnish specimen is referred to L. clematitis, although there are some deviating features, e.g. the variation in the shape of the spore warts, the size of the basidia and the morphology.

The Finnish collection was found on a large wooden (Picea/Pinus) flower pot of Sabal palmetto (Arecaceae) in a greenhouse for tropical plants, where the temperature and air humidity are fairly constant $\left(+17-30^{\circ} \mathrm{C}\right.$ and $\left.70 \%\right)$ all the year round. Whether this exceptional habitat is the reason for the peculiarities observed in our specimen is not clear. We examined the same flower pot half a year later, to make observations on fresh material, but Litschauerella had been overgrown by sterile Hyphodontia breviseta (Karst.) Erikss. and only the cystidia could be observed.

If there is only one rough-spored species of Litschauerella, it is enormously variable. A solution to the problem should be sought with the aid of the SEM and compatibility tests.

Because of the taxonomical problems, the distribution of $L$. clematitis is unclear. In the "wide" sense it has been reported from Denmark (Christiansen 1960), Sweden, Poland (Eriksson \& Ryvarden 1976), 
Germany (Oberwinkler 1966b), France (Bourdot \& Galzin 1928), Spain (Hjortstam et al. 1981, Manjón \& Moreno 1983), the United States (Liberta 1962, Gilbertson \& Blackwell 1987), Canada (Liberta 1962) and New Zealand (Cunningham 1955).

\section{Specimens examined}

Sweden. Västergötland: Töllsjö par., SW of the lake Kulsjön, on well-decayed trunk of Picea abies in mixed Picea forest, 30.V.1976 Hjortstam 6648 (GB). Finland. Uusimaa: Helsinki, Kaisaniemi, Univ. Bot. Garden, green house, on wooden (Picea/Pinus) flower pot of Sabal palmetto (Arecaceae), Grid $27^{\circ} \mathrm{E}$ 6675:386, 22.VIII.1989 Kotiranta 7511 \& Saarenoksa 13589 (H, H.K.).

\section{Lobulicium occultum Larss. \& Hjortst.}

Finland. Kittilän Lappi: Kittilă, Homevuotso State Forest Reserve, in swamp, on fallen, partly hard, decorticated Picea abies together with Phellinus nigrolimitatus (Rom.) Bourd. \& Galz. and inside a wet, strongly brown-rotted (Fomitopsis pinicola (Sw.) Karst.) Picea abies together with Resinicium furfuraceum (Bres.) Parm., in virgin spruce-dominated grass-herb forest, Grid 27²:7519:398-9, 28.VIII.1989 Kotiranta 7571 (H.K.), 7579 (H, H.K.) and $7580(\mathrm{H})$.

For the other collections from Finland, see Kotiranta and Larsson (1990).

Phlebiella lloydii (Liberta) Hjortst. \& Larsson - Fig. 12.

New to Finland. Fruit body resupinate, effused, closely adnate, fairly thin, finely granulose, subceraceous, fairly hard when dry, olive greenish, margin not differentiated, thinning out.

Hyphal system monomitic, hyphae clamped, thinwalled, parallel next to the substrate, more randomly oriented in lower part of subiculum and subhymenium, indefinitely inflated, thin-walled, (1.5-)2.0(3.0) $\mu \mathrm{m}$ wide, clamps very difficult to discern. Cystidia none. Basidia short-cylindrical, finely granulous with golden brown encrustations in CB and IKI, smooth in $\mathrm{KOH}$, pleural, (11-)13-14 x (4.7-)5$5.5 \mu \mathrm{m}$, basally clamped, at first with two or three stout sterigmata, at maturity with four, which are apically very thin, up to $7 \mu \mathrm{m}$ long. Spores shortallantoid, $5.0-6.3 \times 2.0-2.9 \mu \mathrm{m}, \mathrm{L}=5.7, \mathrm{~W}=2.3, \mathrm{Q}$ $=2.1-3.0, \overline{\mathrm{Q}}=2.5($ Kotiranta $8097 a), \mathrm{n}=30$, smooth, thin-walled, $\mathrm{CB}-$, amyloid, except the apiculus.

According to Liberta (1962), the olive-greenish colour of the fruit body is due to the minute olivaceous granules on the basidia. Our specimen however, contains numerous small unicellular algae, which give the colour. The spores of Corticium lloydii drawn

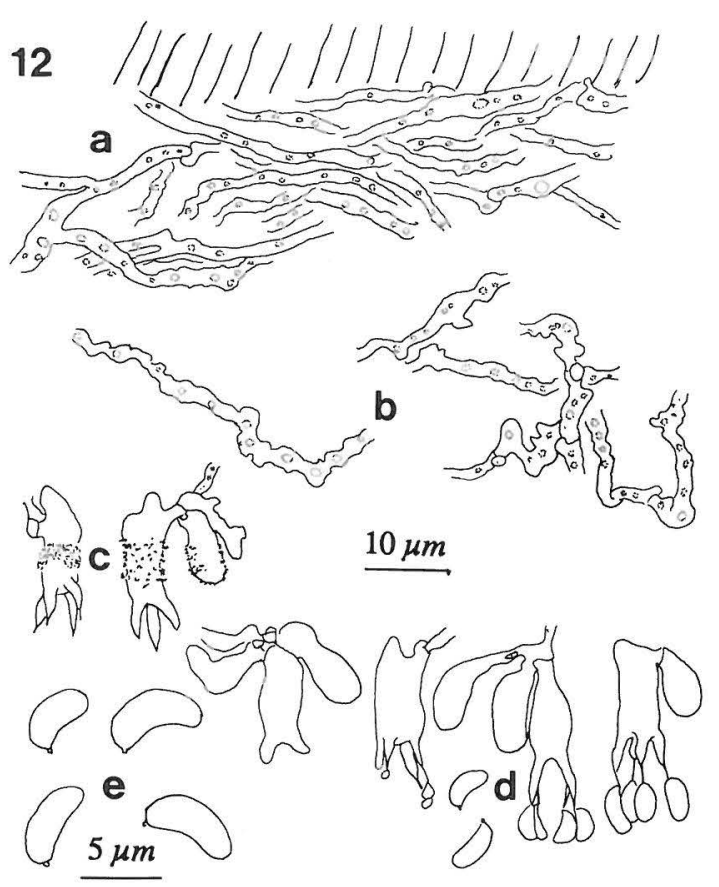

Fig. 12. Phlebiella lloydii (Liberta) Hjortstam \& Larsson. a) basal hyphae in $\mathrm{KOH}$, b) subhymenial hyphae in $\mathrm{KOH}, \mathrm{c}$ ) basidia in IKI, d) basidia in $\mathrm{KOH}$, e) spores in IKI (specimen Kotiranta 8097a, H, H.K.).

by Bourdot and Galzin (1928) are in fact small green algae (Liberta 1962, Oberwinkler 1966b), very similar to those seen by us. The Swedish collection that we studied (see below) is partly greyish, partly faint olive-greenish. The sections made from the greyish part showed mature basidia with typical granules, but no algae. The greenish part contained small cylindrical and globose algae.

$P$. lloydii is a very rare species. It has been reported from Sweden (Bourdot \& Galzin 1928, Hjortstam et al. 1988) and Canada (Liberta 1962), and grows on decorticated, fairly hard pine wood.

\section{Specimens examined}

Sweden. Västergötland: Sydbillingen, $\mathrm{N}$ of Såakullen, on decorticated, decayed (fairly hard) trunk of Pinus sylvestris, in coniferous forest, 11.XI.1976 Hjortstam 7658 \& Hallingbäck (GB); Finland. Etelä-Häme: Luhanka, Lempäă, Leppăjoki W part, on 3-cm-thick, decorticated, hard Pinus sylvestris together with Tubulicrinis subulatus (Bourd. \& Galz.) Donk, in young pine forest with, Vaccinium vitis-idaea, Grid $27^{\circ} \mathrm{E} 68496: 4337$, 23.II.1990 Kotiranta 8097 a (H, H.K.). 

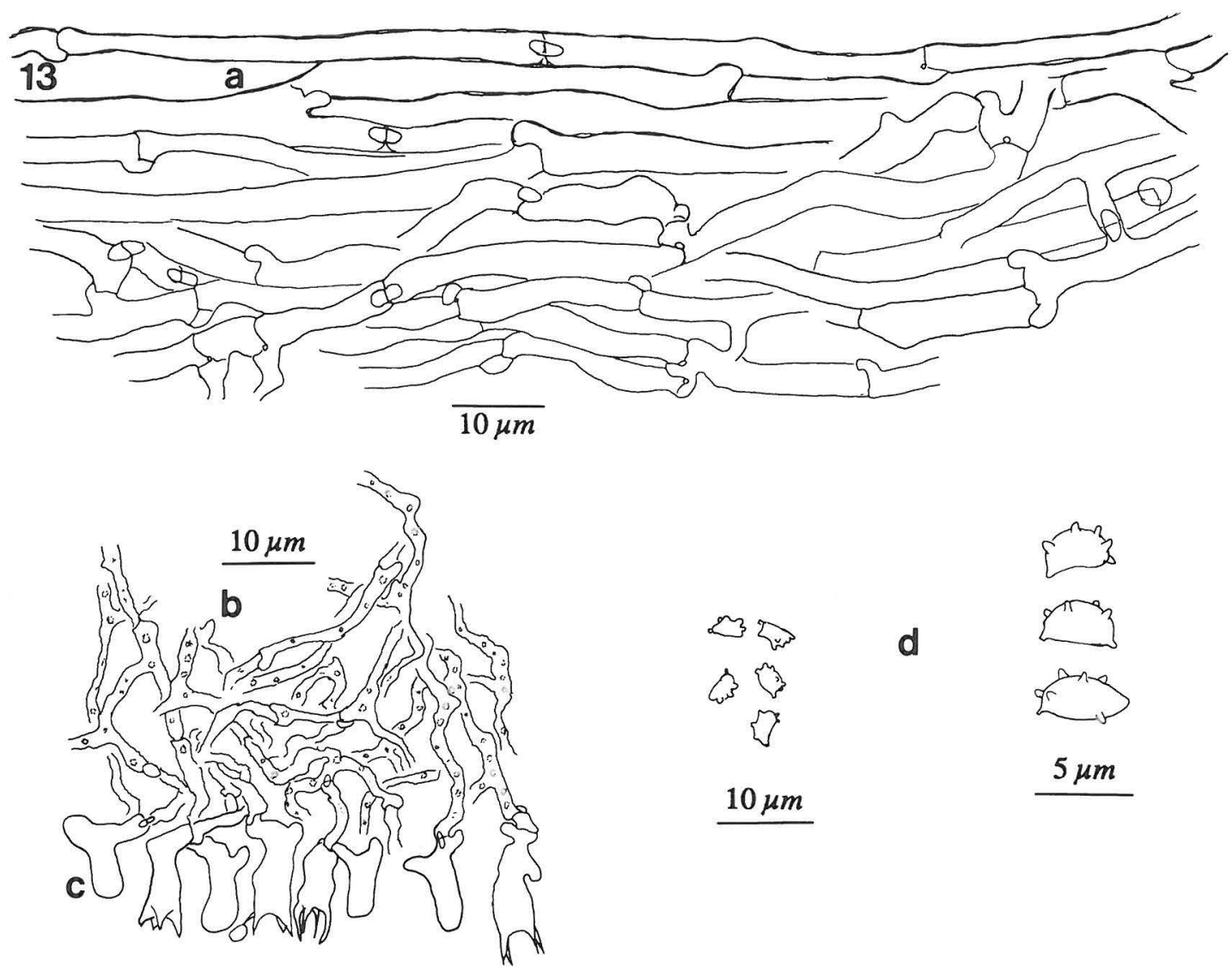

Fig. 13. Phlebiella subflavidogrisea (Litsch.) Oberw. a) basal hyphae, b) context, c) hymenium with basidia, d) spores (specimen Saarenoksa 16989, H, H.K., in KOH).

Phlebiella subflavidogrisea (Litsch.) Oberw. Fig. 13.

Reported earlier from Finland by Hjortstam et al. (1988). Fruit body resupinate, effused, thin, almost smooth to the naked eye, porous with threads under the lens, whitish grey-brown, with pinkish hue, dark red-brown in $\mathrm{KOH}$, margin not differentiated, thinning out.

Hyphal system monomitic, hyphae clamped, subparallel next to the substrate fairly thick-walled, 3.5$5 \mu \mathrm{m}$ wide, lower subicular hyphae and subhymenial hyphae irregularly inflated, with small droplets in $\mathrm{KOH}$, thin-walled, $1-1.5 \mu \mathrm{m}$ wide, clamps hardly discernible. Cystidia none. Basidia short-cylindrical, pleural, $10-12 \times 4-5 \mu \mathrm{m}$, basally clamped, with four, up to $5 \mu \mathrm{m}$ long sterigmata. Spores ellipsoid or even navicular, dorsally sparingly warted, ventrally smooth or with one-two warts only, 3.5-4.5 $\times 2.0$ $2.6 \mu \mathrm{m}, \mathrm{L}=4.0, \overline{\mathrm{W}}=2.4, \mathrm{Q}=1.5-2.0, \overline{\mathrm{Q}}=1.7$ (Saarenoksa 16989), $\mathrm{n}=30$, including the up to $0.5 \mu \mathrm{m}$ long warts, CB- (contents blue), IKI-, often attached in pairs-tetrads.

We were not able to see the brownish colour of the spores mentioned by Hjortstam (1983). P. subflavidogrisea grows on strongly decayed coniferous wood and is a fairly rare species, reported from Sweden (Litschauer 1941, Hjortstam 1973, Larsson 1986), Norway (Hjortstam et al. 1988), Germany (Oberwinkler 1966b), Austria (Oberwinkler 1966b, Hallenberg \& Michelitsch 1983) and Spain (Hjortstam et al. 1981). 


\section{Specimen examined}

Finland. Uusimaa: Tuusula, Lahela, on strongly decayed brown-rotted coniferous log of a small collapsed building, in mixed grass-herb forest, Grid $27^{\circ} \mathrm{E} 6698: 388,27 . V I I I .1989$ Saarenoksa 16989 (H, H.K.).

Sistotrema heteronemum (J. Erikss.) Strid Fig. 14.

New to Finland. Fruit body resupinate, thin, loosely attached, smooth, porous to reticulate, white.

Hyphal system monomitic, basal hyphae next to the substrate sparsely clamped, individual cells up to $360 \mu \mathrm{m}$ long, pigmented, with thickened walls, $\mathrm{CB}+$, 7.5-10 $\mu \mathrm{m}$ wide, outer subicular hyphae thin-walled, $\mathrm{CB}+, 5.3-6.5 \mu \mathrm{m}$ wide, subhymenial hyphae hyaline, richly branched, thin-walled, $\mathrm{CB}+, 4-4.5 \mu \mathrm{m}$ wide. Cystidia none. Basidia urniform, (14-)16-20 x (4-) 4.5-5.0 $\mu \mathrm{m}$, with (6-)8 sterigmata, basally clamped. Spores narrowly ellipsoid, $4.0-5.5 \times 2.0$ $2.8, \mathrm{~L}=4.7, \mathrm{~W}=2.3, \mathrm{Q}=1.7-2.4, \bar{Q}=2.1$ (19.VIII.1986 Issakainen), $\mathrm{n}=30$, with a prominent apiculus, often glued in octads, thin-walled, $\mathrm{CB}+$, IKI-.

As pointed out by Eriksson (1958b), Eriksson and Ryvarden (1973), Strid (1975a) and Eriksson et al. (1984) $S$. heteronemum is a problematic species, combining the characteristics of two closely related genera, Botryobasidium Donk and Sistotrema Fr. The pigmented basal hyphae, the staining of the hyphal walls in CB and the shape of the spores point to Botryobasidium, and the spores in Botryobasidium are cyanophilous (Jülich \& Stalpers 1980) as in $S$. heteronemum. On the other hand, the characteristic basidial morphology is similar to that of Sistotrema.

$S$. heteronemum is a very rare species, reported from Sweden, Norway and Czechoslovakia (Eriksson et al. 1984) and grows on all kinds of debris.

\section{Specimen examined}

Finland. Pohjois-Häme: Konnevesi, Siikakoski, on dead fern(?), in herb-rich mixed forest, alt. $95-110 \mathrm{~m}$, Grid $27^{\circ} \mathrm{E}$ 6945:466, 19.VIII.1986 Issakainen (OULU, H.K.).

Sistotrema sp. Kotiranta 7817 - Fig. 15.

Fruit body resupinate, smooth, very thin, when fresh appearing as a greyish bloom, when dry invisible to the naked eye.

Hyphal system monomitic, hyphae more or less straight, clamped, 3-4 $\mu \mathrm{m}$ wide, thin-walled, CB-, IKI-. Cystidia none. Basidia emerging from the basal hyphae, urniform, (10-)12-14(-17) x (4-)5-6 $(-7) \mu \mathrm{m}$, basally clamped, with (4-)6-8, up to $6 \mu \mathrm{m}$ long sterigmata. Spores small, ovoid, somewhat pipshaped, widest at the apical part, $2.8-4.0 \times 2.0-2.8$, $\mathrm{L}=3.3, \mathrm{~W}=2.3, \mathrm{Q}=1.1-1.7, \bar{Q}=1.4$ (Kotiranta $7817), \mathrm{n}=30$, with a relatively large apiculus, up to $0.8 \mu \mathrm{m}$ long, thin-walled, CB-, IKI-.

The basidia of this specimen are similar to those seen in Sistotrema. However, the sparse hyphae observed were not oil-filled, or contained only a little oil. In one mount there was a bulbil-like structure,

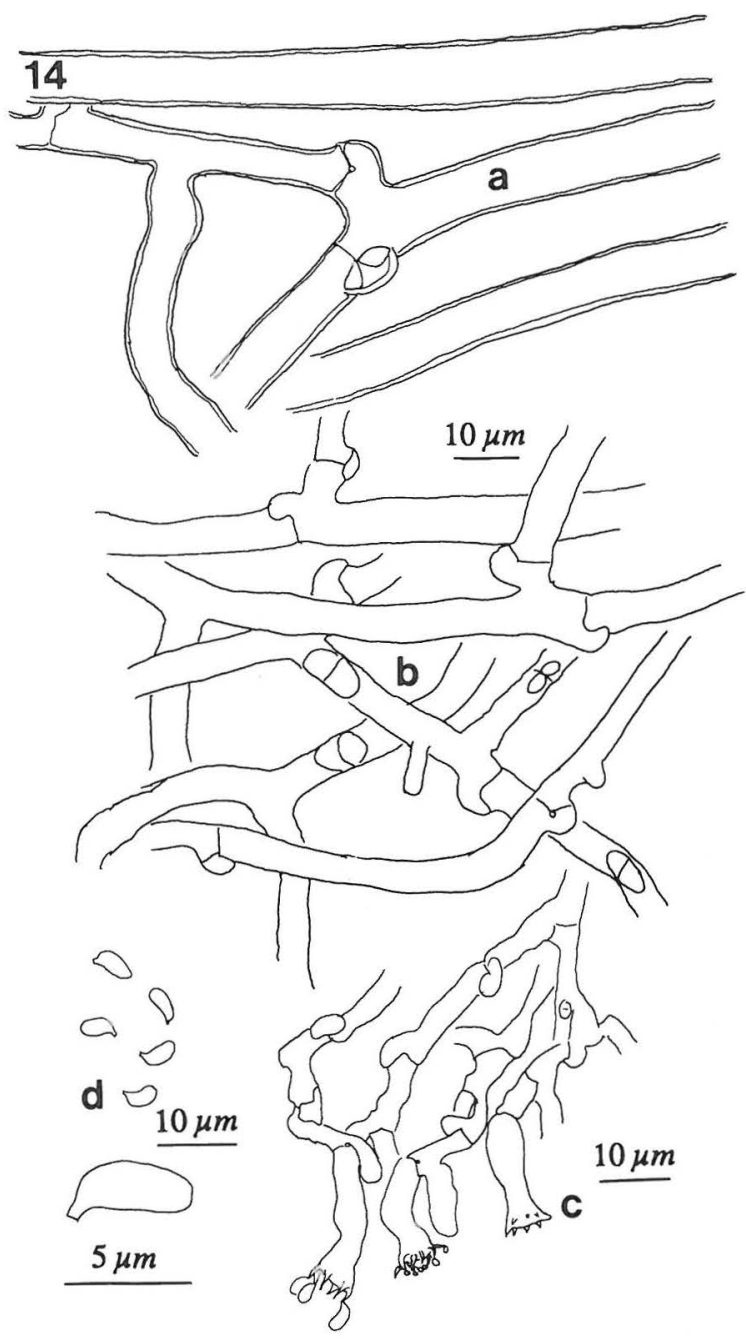

Fig. 14. Sistotrema heteronemum (J. Erikss.) Strid. a) pigmented basal hyphae, b) hymenium with basidia, d) spores in IKI (specimen Issakainen 19.VIII.1986, OULU, H.K., in CB). 


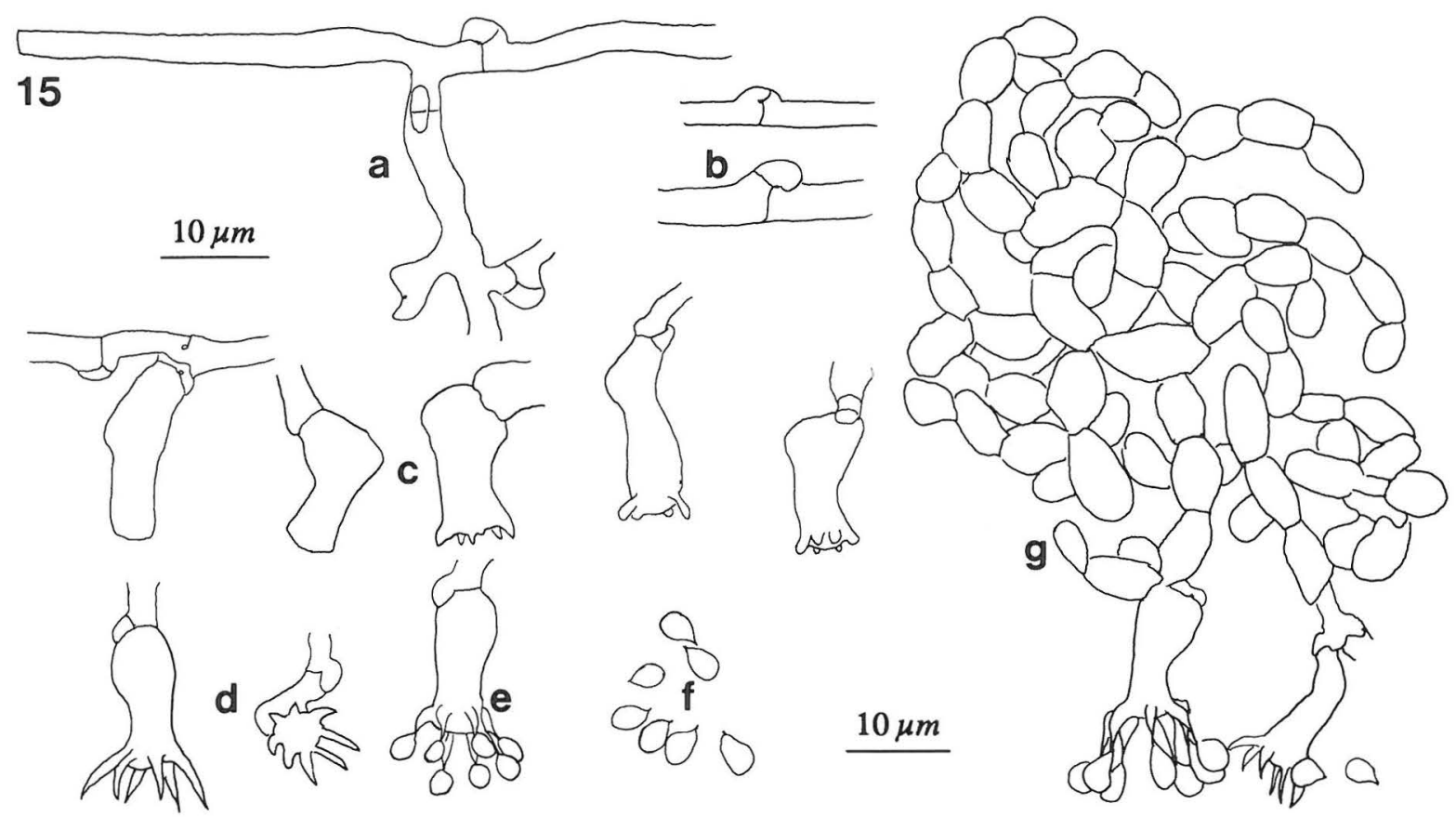

Fig. 15. Sistotrema sp. Kotiranta 7817. a) basal hyphae in IKI, b) clamps in KOH, c) unripe basidia in KOH, d) ripe basidia in IKI and e) in CB, f) spores in KOH, g) Burgoa (?) with Sistotrema sp. (see text) in KOH (specimen Kotiranta 7817, H.K.).

somewhat reminiscent of the drawing of Burgoa sp. (Eriksson et al. 1984: 1348) in a culture of Sistotrema oblongisporum M.P. Christ. \& K. Hauersl. In our specimen, however, the cells were simple septate. Whether the basidia really arose from clampless hyphae could not be confirmed. The possibility that this is a clampless Burgoa Goid. cannot be excluded (see e.g. Weresub \& LeClair 1971: 2206).

In Hallenberg's (1984b) study of the Sistotrema brinkmannii complex, one species ( $S$. farinaceum Hallenb.) has spores of the same size as the Finnish collection, but they are subglobose. Moreover, the fruit body of $S$. farinaceum is farinaceous, loosely attached and whitish. Paullicorticium delicatissimum (Jacks.) Liberta has obovate to obpyriform basidia and oblong to ellipsoid spores (Liberta 1962).

\section{Specimen examined}

Finland. Perä-Pohjanmaa: Rovaniemi rural comm., Pisavaara Strict Nat. Res., Sorvannulikka N slope, on dead leaves of Populus tremula and needles of Picea abies, in virgin sprucedominated forest, Grid $27^{\circ}$ E 7358-9:415-6, 6.IX.1989 Kotiranta 7817 (H.K.).
Sistotremastrum niveocremeum (v. Höhn. \& Litsch.) J. Erikss. - Fig. 16.

Reported earlier from Finland by Ulvinen et al. (1981) and Kotiranta and Larsson (1990). Fruit body resupinate, thin, almost smooth to the naked eye, porose under the lens, white, margin not differentiated, thinning out.

Hyphal system monomitic, basal hyphae richly branched, clamped, 3-4 $\mu \mathrm{m}$ wide, with slightly thickened walls, CB-, IKI-, subhymenial hyphae richly branched, clamped, 3-4 $\mu \mathrm{m}$ wide, thin-walled, CB-, IKI-. Cystidia none. Basidia tubular, slightly constricted, (16-)20-26(-29) × 6-8 $\mu \mathrm{m}$, basal part with thickened walls, basally clamped, with six sterigmata that disintegrate after spore liberation. Spores ellipsoid or subcylindrical or suballantoid, $5.6-8.0 \times$ 2.2-4.2 $\mu \mathrm{m}, \mathrm{L}=6.9, \overline{\mathrm{W}}=3.2, \mathrm{Q}=1.8-2.8, \overline{\mathrm{Q}}=2.1$ (Kotiranta 8060), $\mathrm{n}=30$, thin-walled, CB-, IKI-.

$S$. niveocremeum varies in its fruit body thickness in Europe and North America (Hallenberg 1984a), and the size of the spores is variable. Specimens with shorter spores than usual have been reported from Iran (Hallenberg 1978; sp. 4-6.5 × 2-3 $\mu \mathrm{m}$ ) 
and Brazil (Hjortstam \& Bononi 1987), and a longspored $(8.5-11 \times 3.5-4.5 \mu \mathrm{m})$ specimen were found in Sweden (Hallenberg 1984a). Hallenberg (1984a) tested four European and three Canadian specimens and found only two Canadian ones to be intercompatible.

$S$. niveocremeum is nowhere particularly rare. It has been reported from Sweden (Eriksson 1958a, Hjortstam 1973, Strid 1975a), Norway (Strid 1975b), Denmark (Christiansen 1960), Germany (Oberwinkler 1966b, Kreisel 1987), Austria (v. Höhnel \& Litschauer 1908, Hallenberg \& Michelitsch 1983), Switzerland (Breitenbach \& Kränzlin 1986), Czechoslovakia, Great Britain (Jülich 1984), France (Bourdot \& Galzin 1928), Spain (Hjortstam et al. 1981, Tellería \& Truchero 1981, Dueñas \& Telleria 1988), and outside Europe from the Soviet Union, Iran (Hallenberg 1978), Argentina (Hjortstam \& Ryvarden 1985), Brazil (Hjortstam \& Bononi 1987) and Canada (Oberwinkler 1966b, Hallenberg 1984a).

$S$. niveocremeum has a wide range of host species. It is usually collected from deciduous trees, and records from softwood are rare (e.g. Eriksson 1958a, Hallenberg 1984a, Ginns 1986).

\section{Specimen examined}

Finland. Etelä-Häme: Luhanka, Lempăă, Leppăjoki W part, on strongly decayed, white-rotted deciduous branch on ground, in deciduous, brook-side grass-herb forest, Grid $27^{\circ} \mathrm{E} 68496: 4337$ 8, Kotiranta 8060 (H.K.).

\section{Sistotremella perpusilla Hjortst. - Fig. 17.}

New to Finland. Fruit body resupinate, thin, smooth to the naked eye, pruinose under the lens, soft when dry, margin not differentiated, thinning out, pale greyish ochre.

Hyphal system monomitic, hyphae richly branched, clamped, thin-walled, 1.5-2.5 $\mu \mathrm{m}$ wide. Cystidia none. Basidia at first pyriform, later urni-

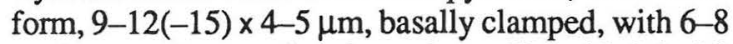
sterigmata. Spores abundant, short-ellipsoid, 3.0-4.0 $\times 2.0-2.9 \mu \mathrm{m}, \mathrm{L}=3.2, \mathrm{~W}=2.3, \mathrm{Q}=1.2-1.6, \mathrm{Q}=1.4$ (Kotiranta 6793), $\mathrm{n}=30$, often attached in pairsoctads or chains, uniguttulate, thick-walled, $\mathrm{CB}+$, IKI-.

$S$. perpusilla is a rare species, reported from Sweden, Norway, Denmark, Germany (Eriksson et al. 1984) and Spain (Dueñas \& Tellería 1988). It grows on both angiosperms and gymnosperms.

\section{Specimen examined}

Finland. Uusimaa: Inkoo, Sommaröarna (Sommarn), on old, partly charred coniferous timber, together with Hyphoderma

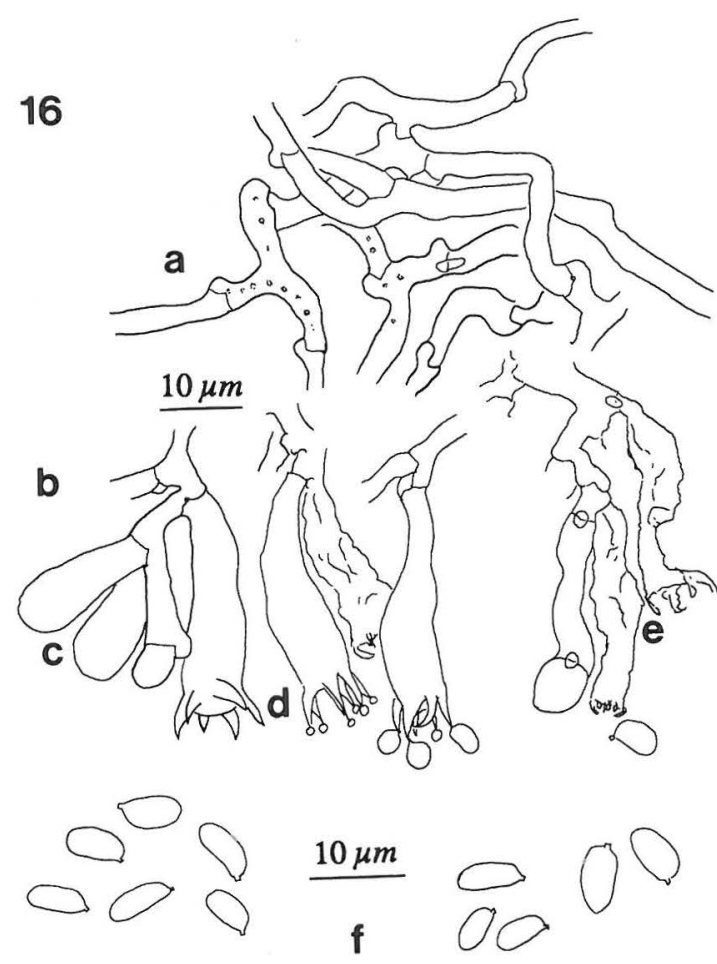

Fig. 16. Sistotremastrum niveocremeum (v. Höhn. \& Litsch.) J. Erikss. a) subicular hyphae, b) hymenium, c) basidioles, d) ripe basidia, e) collapsed basidia, f) spores (specimen Kotiranta 8060 , H.K., in IKI).

praetermissum (Karst.) J. Erikss. \& Strid, in a small collapsed house, Grid 27E 6648:346, 25.V.1988 Kotiranta 6793 (H.K.).

Steccherinum litschaueri (Bourd. \& Galz.) J. Erikss.

Finland. Varsinais-Suomi: Karjalohja, Karkali Strict Nat. Res., on small, strongly decayed Picea abies on ground, in sprucedominated grass-herb forest, Grid $27^{\circ} \mathrm{E} 6686: 322,19$.VIII. 1980 Kotiranta 2097, Kauppila \& Niemelä (H.K.). Oulun Pohjanmaa: Kiiminki, Keskikylä, Pöksälänkangas, on decayed Alnus in spruce-dominated grass-herb forest, Grid $27^{\circ} \mathrm{E} 7227: 445$, 14.IX.1974 M. Ohenoja 3 (GB 24681, OULU). Kittilän Lappi: Kittila,, Homevuotso State For. Res., on Prunus padus litter, in virgin spruce-dominated grass-herb forest, Grid $27^{\circ} \mathrm{E}$ 7519:398-9, 27.VIII.1989 Kotiranta 7551 (H.K.).

Steccherinum oreophilum Linds. \& Gilbertson

Finland. Pohjois-Häme: Toivakka, Huikko, Koskela $300 \mathrm{~m}$ SW, on Populus tremula branches, in mixed forest of Vaccinium myrtillus site type, Grid $27^{\circ} \mathrm{E} 689: 45,20 . X .1979$ E. Ohenoja (OULU). 
For the other collections from Finland, see Niemela and Saarenoksa (1985).

Trechispora praefocata (Bourd. \& Galz.) Liberta -Fig. 18.

Reported earlier from Finland by Kotiranta and Larsson (1990). Fruit body resupinate, fairly thin, loosely adnate, finely byssoid to farinaceous to the naked eye, arachnoid to finely porose under the lens, margin fibrillose or rhizomorphic, white to pale olive-greenish.

Hyphal system monomitic, hyphae mostly 1.0 $1.5 \mu \mathrm{m}$ wide, covered with scattered, normally acerose crystals, sparingly clamped, with ampullaceous swellings at septa, up to $7.5 \mu \mathrm{m}$ wide, thin-walled. Cystidia none. Basidia terminal, cylindrical, slightly constricted, (11-)12-15(-18) x 5-6 $\mu \mathrm{m}$, basally clamped, with four sterigmata. Spores ellipsoid, covered with spines up to $1.0 \mu \mathrm{m}$ long, 5.7-7.1 x 4.1$5.6 \mu \mathrm{m}, \mathrm{L}=6.3, \mathrm{~W}=5.0, \mathrm{Q}=1.1-1.5, \mathrm{Q}=1.3$

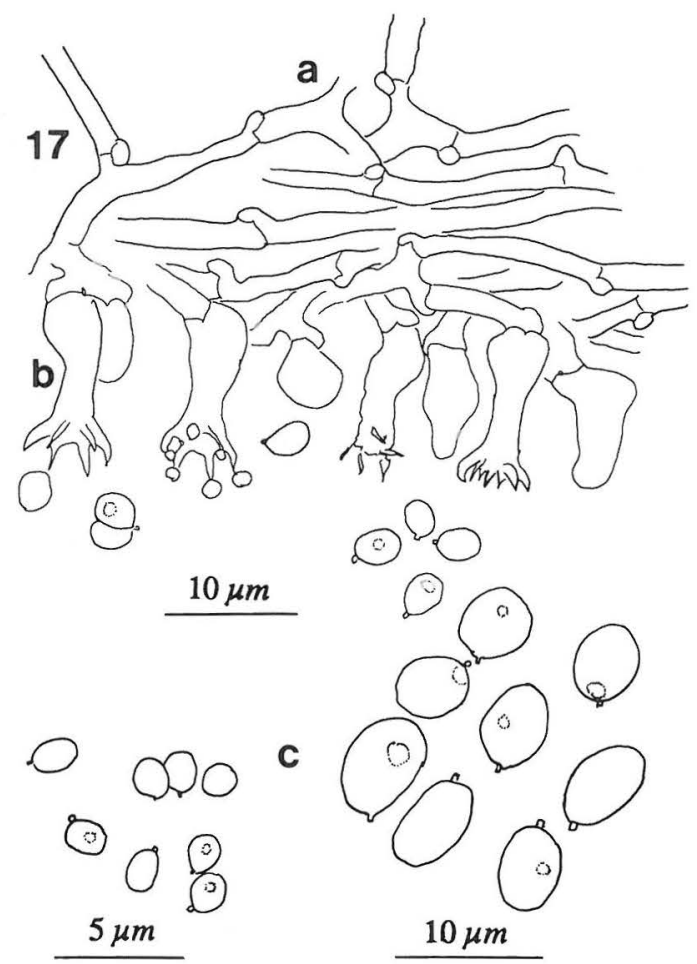

Fig. 17. Sistotremella perpusilla Hjortst. a) context hyphae, b) hymenium with basidia and spores, c) spores (specimen Kotiranta 6793, H.K., in CB).
(Kotiranta $7344 \&$ Saarenoksa), $\mathrm{n}=30$; spines up to $1.0 \mu \mathrm{m}$ long, $5.0-6.0 \times 3.6-5.0 \mu \mathrm{m}, \mathrm{L}=5.3, \mathrm{~W}=4.0$, $\mathrm{Q}=1.1-1.4, \mathrm{Q}=1.2$ (Saarenoksa 51989), $\mathrm{n}=30$; spines up to $1.3 \mu \mathrm{m}$ long, $5.0-6.0 \times 4.0-5.0 \mu \mathrm{m}, \mathrm{L}=$ $5.6, \mathbb{W}=4.8, Q=1.1-1.4, \bar{Q}=1.2$ (Saarenoksa $40589) \mathrm{n}=30, \mathrm{CB}-$, IKI- (measurements include the spines).

One of the specimens (Kotiranta 7344 \& Saarenoksa), reported already by Kotiranta and Larsson (1990), differs slightly from the other specimens examined. Its basidia are slightly longer (13.5-18 x $5.5-6.0 \mu \mathrm{m})$ and the spores are also bigger. The basal hyphae are up to $3.5 \mu \mathrm{m}$ wide, and are covered by crystals similar to those in T. fastidiosa (Pers.) Liberta (drawn by Liberta 1973: 1886). Hjortstam et al. (1988), however, do not mention any kind of crystals in $T$. fastidiosa, and the basidia of T. fastidiosa are (14.5-)25-30(-35) $\mu \mathrm{m}$ long (Liberta 1973, Hjortstam et al. 1988).

$T$. praefocata is nowhere common, but has been reported from Sweden, Norway (Hjortstam et al.
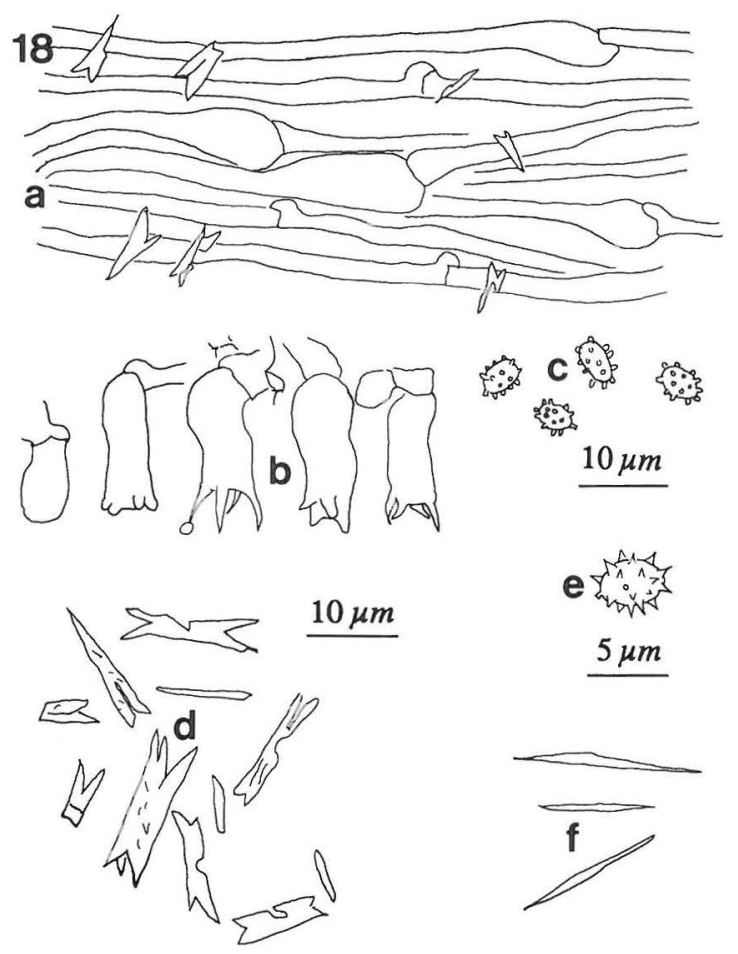

$5 \mu m$

Fig. 18. Trechispora praefocata (Bourd. \& Galz.) Liberta. a) subicular hyphae, b) basidia, c) spores, d) crystals (specimen Kotiranta 7344 \& Saarenoksa, H, H.K., in $\mathrm{KOH}$ ), e) spore (specimen Saarenoksa 40589, H, in $\mathrm{KOH}$ ), f) crystals (specimen Saarenoksa 51989, H, in $\mathrm{KOH}$ ). 

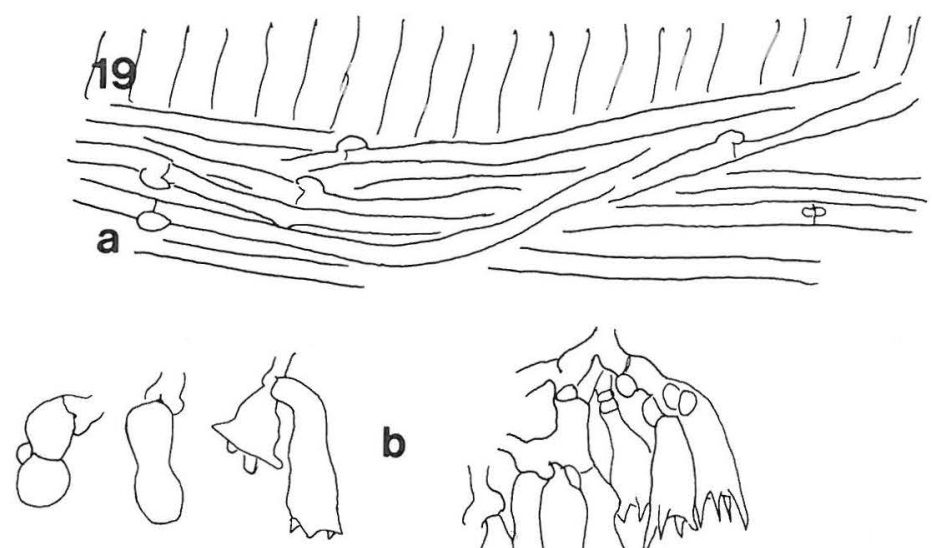

b

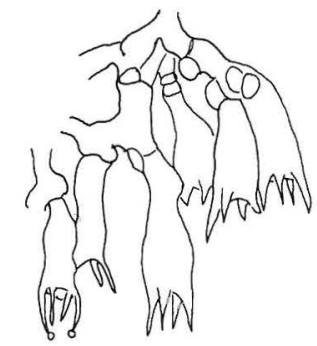

$10 \mu m$
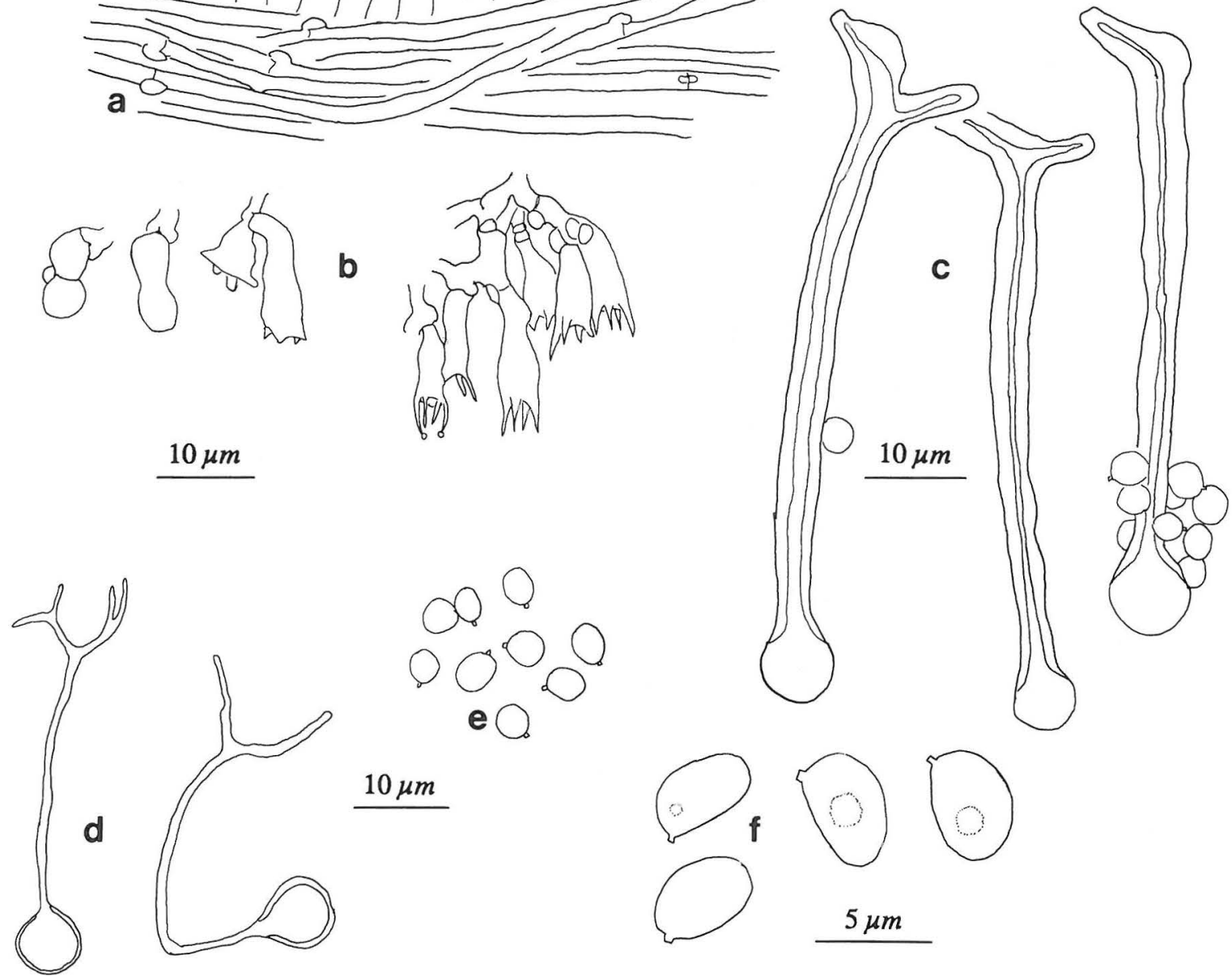

Fig. 19. Tubulicrinis accedens (Bourd. \& Galz.) Donk. a) basal hyphae in KOH, b) basidia in IKI, c) cystidia in IKI, d) cystidia in $\mathrm{KOH}$, e) spores in IKI (specimen Kotiranta 5859, K-H. Larsson \& Hjortstam, H.K.), f) spores in CB (specimen Kotiranta 7319, H.K.).

1988), Denmark (Christiansen 1960), France (Bourdot \& Galzin 1928), Spain (Dueñas 1986) and outside Europe from Iran (Hallenberg 1981) and the United States (Gilbertson \& Budington 1970, Gilbertson 1974). T. praefocata grows on all kinds of debris.

\section{Specimens examined}

Finland. Uusimaa: Helsinki, Viikki, on Picea abies, 9.VI.1989 Kotiranta 7344 \& Saarenoksa (see Kotiranta \& Larsson 1990). Helsinki, Viikki, Säynäslahti, on decorticated, soft Sambucus racemosa branches, in moist broad-leaved grass-herb forest, Grid $27^{\circ}$ E 6680:388, 8.X.1989 Saarenoksa 51989 (H). Helsinki, Viikki, Säynäslahti, on decaying leaves of Matteuccia stru- thiopteris together with Trechispora sp., in moist deciduous (Alnus glutinosa, Prunus padus, Salix caprea) shore grass-herb forest, Grid $27^{\circ} \mathrm{E}$ 6680:388, 14.X.1989 Saarenoksa 40589 (H).

Tubulicrinis accedens (Bourd. \& Galz.) Donk - Fig. 19.

Reported earlier from Finland by Hjortstam (1984). Fruit body resupinate, thin, smooth to the naked eye, hypochnoid, glancing under the lens due to the protruding cystidia, margin not differentiated, very thin but clear, pale whitish to pale olivaceous green.

Hyphal system monomitic, hyphae next to the substrate parallel, fairly sparingly clamped, up to 
$2 \mu \mathrm{m}$ wide, thin-walled, CB-, IKI-, subhymenial hyphae richly branched, clamped, 2.5-3.0 $\mu \mathrm{m}$ wide, thin-walled, CB-, IKI-. Cystidia numerous, capitate, (42-)51-66(-72) × 3-4.5 $\mu \mathrm{m}$, cystidial neck 2.1$3.0(-3.7) \mu \mathrm{m}$ wide, apex (5.0-)6.0-8.5 $\mu \mathrm{m}$ wide, basally thick-walled, capillary lumen gradually expanded, cystidial walls $\mathrm{CB}-$ (plasma $\mathrm{CB}+$ ), IKI pale grey, or with a greyish hue only, dissolving in $\mathrm{KOH}$. Basidia conical, at first constricted, later almost stalked, (8-)9-12(-14) x (3-)3.5-4.5 $\mu \mathrm{m}$, basally clamped, with four sterigmata, very thin-walled, CB-, IKI-. Spores broadly ellipsoid-subglobose, $3.7-5.0 \times 2.5-3.4 \mu \mathrm{m}, \mathrm{L}=4.2, \mathrm{~W}=2.9, \mathrm{Q}=1.2-1.7$, $\overline{\mathrm{Q}}=1.4$ (Kotiranta 7319), $\mathrm{n}=30 ; 3.5-4.3 \times 2.7-$ $3.5 \mu \mathrm{m}, \mathrm{L}=4.0, \mathrm{~W}=3.2, \mathrm{Q}=1.1-1.4, \mathrm{Q}=1.2$ (Kotiranta 5859, Larsson \& Hjortstam), $\mathrm{n}=30$, often attached around the cystidial apices, uniguttulate (CB), thin-walled, CB-, IKI-.

$T$. accedens, as pointed out by Hjortstam et al. (1988), has some variation in its spore shape. The two collections examined by us differ in their spore morphology. The one collected in spring (see below), has the same shape as drawn in Hjortstam et al. (1988: $1526, \mathrm{i}=$ Hjortstam 3049 ), and the $\bar{Q}$ value is 1.4 . The other collection is similar to Larsson 1231 (Hjortstam et al. 1988: 1526, g), with the value of 1.2. The specimens are otherwise similar.

T. accedens grows preferably on conifers (Hjortstam et al. 1988), and is nowhere common. It has been reported from Sweden (Hjortstam 1973, 1979a, Strid 1975a), Norway, Denmark (Hjortstam et al. 1988), Germany (Oberwinkler 1966a), Austria (Hallenberg \& Michelitsch 1983), Switzerland (Breitenbach \& Kränzlin 1986), Czechoslovakia (Jülich 1984), France (Bourdot \& Galzin 1928), Spain (Tellería \& Truchero 1981) and outside Europe from the Soviet Union (Parmasto 1966), Canada (Weresub 1953, Liberta 1966, Martin \& Gilbertson 1977) and the United States (Weresub 1953, Liberta 1964).

\section{Specimens examined}

Finland. Uusimaa: Inkoo, Sommaröarna (Sommarn), on strongly decayed coniferous (?Pinus) timber, of a small collapsed house, Grid 27E 6648:346, 25.V.1989 Kotiranta 7319 (H.K.). Etelä-Häme: Padasjoki, Vesijako Strict Nat. Res., on decorticated, strongly decayed Picea abies, in virgin spruce-dominated forest with Vaccinium myrtillus, Grid $27^{\circ} \mathrm{E}$ 6808:398, 2.X.1984 Kotiranta 5859, Larsson \& Hjortstam (H.K.).

Tubulicrinis globisporus Larsson \& Hjortst. Fig. 20.

New to Finland. Fruit body resupinate, very thin, almost invisible to the naked eye, under the lens pilose, margin not differentiated, white.
Hyphal system monomitic, basal hyphae clamped, not especially richly branched, (2.5-)3.5 $\mu \mathrm{m}$ wide, with slightly thickened walls, CB-, IKI-, subhymenial hyphae richly branched, clamped, $3.5 \mu \mathrm{m}$ wide, thin-walled, CB-, IKI-. Cystidia abundant, cylindrical, (73-)85-112 x 5-6 $\mu \mathrm{m}$ (middle part), thickwalled, $\mathrm{CB}-$, strongly amyloid, partly dissolving (mostly the basal part) or swelling in $\mathrm{KOH}$ or unchanged; capillary lumen gradually expanding to the thin-walled, obtuse apex (12-)15-22 x 4.5-6 $\mu \mathrm{m}$. Basidia terminal, subclavate, (11-)13-17 x 5.0 $5.5 \mu \mathrm{m}$, basally clamped, with four, up to $5 \mu \mathrm{m}$ long sterigmata, thin-walled, CB-, IKI-. Spores almost globose, $4.0-5.0 \mu \mathrm{m}$ in diam, often attached around the cystidia, thin-walled, CB-, IKI-.

T. globisporus is a rare species, reported from Sweden (Hjortstam \& Larsson 1978, Hjortstam 1979a, Hjortstam et al. 1988), Norway (Aanstad \& Ryvarden 1987, Hjortstam et al. 1988), Austria (Hjortstam et al. 1988), Germany, France, Italy (Oberwinkler 1966a, as T. cf. callosus G.H. Cunningham) and Canada (Hjortstam \& Larsson 1978). All the reports are from coniferous wood, mostly pine.

\section{Specimen examined}

Finland. Inarin Lappi: Inari, Kessi, Paloselkäjärvi, on small decorticated Pinus sylvestris branch on the ground, together with Globulicium hiemale (Laurila) Hjortstam in virgin, poor pine heath forest with Empetrum nigrum ssp. hermaphroditum, Ledum palustre and Vaccinium vitis-idaea, Grid $27^{\circ} \mathrm{E} 7653: 558$, 29.VIII.1989 Kotiranta $7613 b$ (H.K.).

Tubulicrinis strangulatus Larsson \& Hjortst. - Fig. 21.

New to Finland. Fruit body resupinate, at first very thin, appearing to the naked eye as whitish or greyish bloom, later greyish ochre, porose, pilose under the lens.

Hyphal system monomitic, basal hyphae parallel to the substrate, clamped, $3.5-4.0 \mu \mathrm{m}$ wide, with thickened walls, CB-, IKI-, subhymenial hyphae richly branched, clamped, $3.5 \mu \mathrm{m}$ wide, thin-walled, CB-, IKI-. Cystidia numerous, cylindrical, 55-96 x 6-8 $\mu \mathrm{m}$ (middle part), thick-walled, $\mathrm{CB}-$, amyloid, in $\mathrm{KOH}$ strongly swelling (up to $16 \mu \mathrm{m}$ ), soon disappearing, leaving only the $2 \mu \mathrm{m}$ wide, gradually widening or abrupt capillary lumen and the thin-walled, 5.5-8 $\mu \mathrm{m}$ wide, crystal-covered, obtuse apex visible. Basidia subclavate, sometimes constricted and stalked, 10-14.5 × 4-6 $\mu \mathrm{m}$, with four, up to $4.5 \mu \mathrm{m}$ long, very thin sterigmata, basally clamped, very 

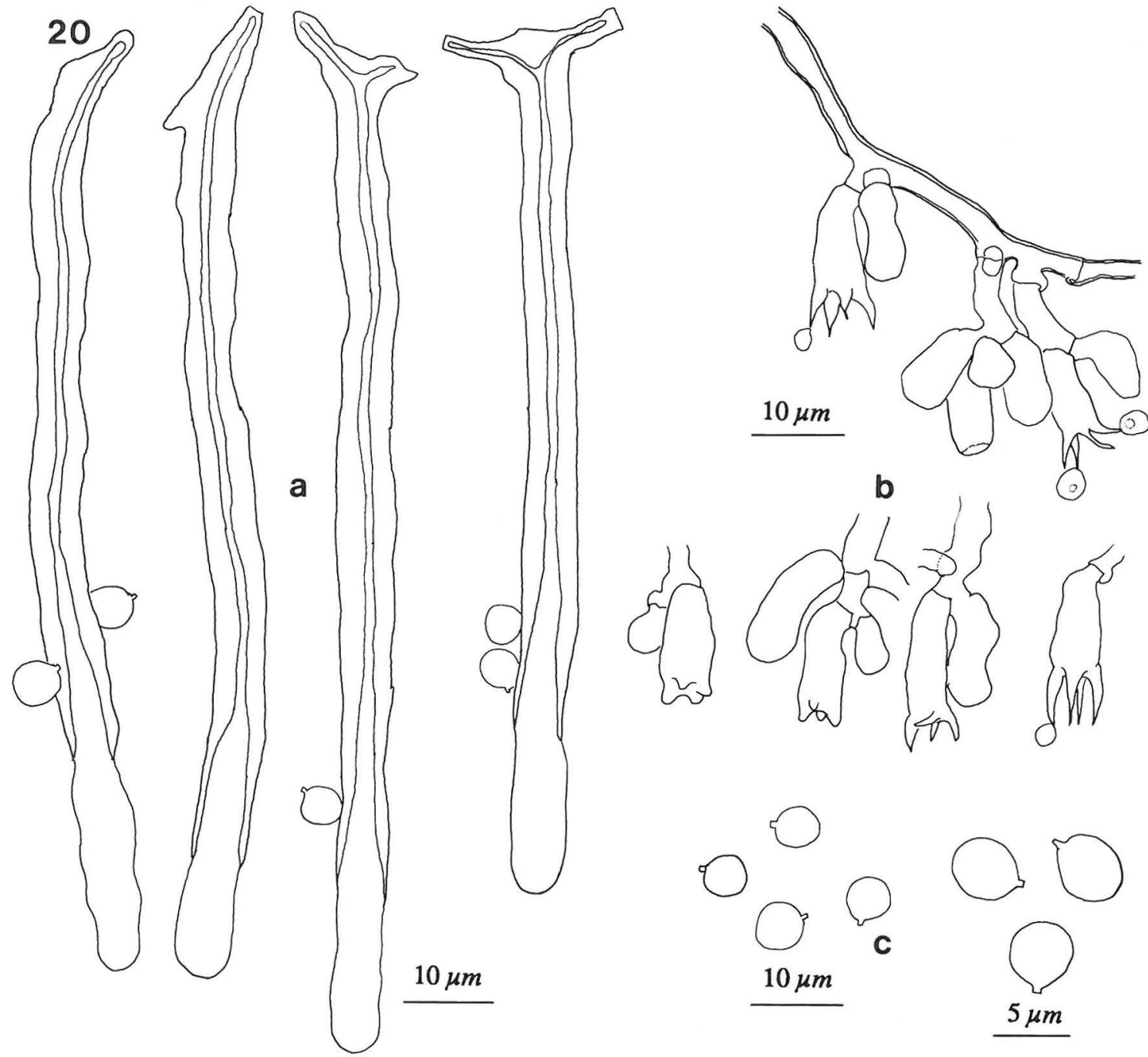

Fig. 20. Tubulicrinis globisporus Larsson \& Hjortst. a) cystidia, b) basidia with spores, c) spores (specimen Kotiranta 7613b, H.K., in IKI).

thin-walled, CB-, IKI-. Spores short-allantoid, adaxial side concave, $4.6-6.8 \times 2.2-3.0 \mu \mathrm{m}, \mathrm{L}=5.3, \mathrm{~W}=$ 2.6, $\mathrm{Q}=1.8-2.3, \bar{Q}=2.0$ (Kotiranta $7409 \&$ Manner koski), $\mathrm{n}=30 ; 4.6-6.1 \times 2.1-2.7 \mu \mathrm{m}, \mathrm{L}=5.2, \mathrm{~W}=2.5$, $\mathrm{Q}=1.8-2.4, \bar{Q}=2.1$ (Kotiranta 7796), $\mathrm{n}=30$, thinwalled, $\mathrm{CB}-$, IKI-.

The Finnish material of $T$. strangulatus deviates from the common $T$. borealis J. Erikss. in having thin-walled, inamyloid basidia and wider spores. $T$. strangulatus is rare, but has been reported from Sweden, Norway (Hjortstam \& Larsson 1986) and Romania (Hallenberg 1986). It grows mainly on coniferous trees in undisturbed forests (Hjortstam et al. 1988).

\section{Specimens examined}

Finland. Etelä-Häme: Ruovesi, Keinumäki E, Musturi State Forest Res., on very decayed, decorticated Picea abies on ground, together with Hyphoderma praetermissum, in virgin, spruce-dominated forest with Vaccinium myrtillus, Grid $27^{\circ} \mathrm{E}$ 6865:362, 14.VI.1989 Kotiranta 7409 \& Mannerkoski (H, H.K.). Perä-Pohjanmaa: Rovaniemi rural comm., Hyypiökivalo, on decorticated, wet $P$ icea abies fallen over a small brook, in virgin spruce forest with Hylocomium and Vaccinium myrtillus, Grid $27^{\circ} \mathrm{E} 7358: 487,4 . I X .1989$ Kotiranta 7796 (H.K.). 

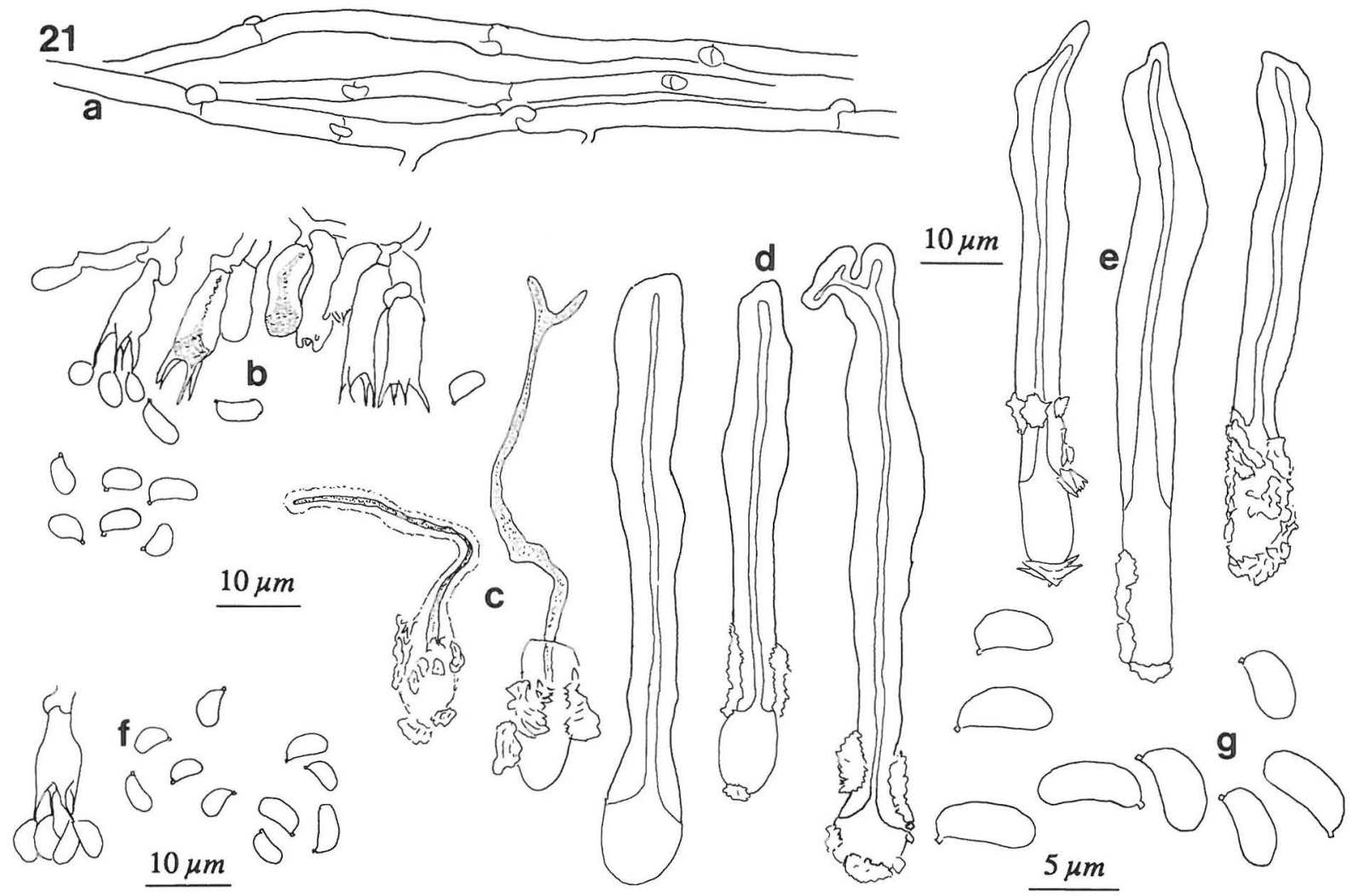

Fig. 21. Tubulicrinis strangulatus Larsson \& Hjortst. a) basal hyphae in $\mathrm{KOH}$, b) basidia and spores in $\mathrm{KOH}$, c) cystidia in $\mathrm{KOH}$, d) cystidia in IKI, e) cystidia in IKI, f) basidia and spores in IKI, g) spores in IKI (specimens Kotiranta 7409 \& Mannerkoski, H, H.K., a, b, e, g; Kotiranta 7796, H.K., c, d, f).

\section{Discussion}

A considerable number of the species reported in this paper, were collected either in virgin forests or from the timber of collapsed houses. Nowadays, unexploited forests are situated mainly in northern Finland, whereas ruined hay barns and other buildings can be found anywhere.

An interesting phenomenon is in the similarity of the species composition of the Aphyllophorales of virgin forests and old timber. Common, widely distributed species with a wide ecological range are naturally found in both "biotopes" and, of course, the diversity of species is greater in old forests. However, some species such as Asterostroma laxum and Phlebiella subflavidogrisea were reported earlier only from the virgin forest of the Pisavaara Strict Nature Reserve near the Polar circle. Now, they were collected in southern Finland on the timber of collapsed houses. The remains of such houses also harbour some other species usually considered inhabitants of undisturbed forests. The southernmost Finnish collection of Crustoderma dryinum (Berk. \& Curt.) Parm. originated from the same building as the finds of $A$. laxum and $P$. subflavidogrisea. Also Tubulicrinis accedens, earlier reported from the Vesijako Strict Nature Reserve in Padasjoki, has now been reported on the remains of a cabin on a small, almost treeless island in the Gulf of Finland.

Similar occurrence, in both virgin forests and collapsed houses, is known among some polypores, e.g. Phellinus nigrolimitatus (Rom.) Bourd. \& Galz. (Niemelä \& Kotiranta 1982). In Estonia also the author Kotiranta found $P$. nigrolimitatus on the strongly decayed logs of an old abandoned building.

Acknowledgements. Dr. Tuomo Niemelä (Helsinki) gave valuable advice, and the English of this paper was revised by Ms Anna A. Damström, M.A. 


\section{References}

Aanstad, S. \& Ryvarden, L. 1987: Aphyllophorales on wooden fences in Norway. - Windahlia 17:49-54.

Boidin, J. 1957: Hétérobasidiomycètes saprophytes et Homobasiomycètes résupinés 1 . Catalogue raisonné des espèces de la région de Samoěns (Alpes de Haute-Savoie). - Publ. Mus. Natl. Hist. Nat. 17:113-130.

Boidin, J. 1958: Hétérobasidiomycètes saprophytes et Homobasidiomycètes résupinés 3. Peniophora clematitis Bourd. et Galz. - Ann. Univ. Lyon C 10:29-40.

Boidin, L. \& Lanquetin, P. 1971: Basidiomycètes Corticiaceae de la République Centrafricaine 3. Le genre Hypochnicium Eriksson. - Cahiers Maboké 9:89-93.

Bondarceva, M.A. \& Parmasto, E.H. 1986: Aphyllophorales. Familiae Hymenochaetaceae, Lachnocladiaceae, Coniophoraceae, Schizophyllaceae. (Clavis Diagn. Fung. URSS 1) - 192 pp. Leningrad.

Bourdot, H. \& Galzin, A. 1928 (1927): Hyménomycètes de France. Hetérobasidiés-Homobasidiés Gymnocarpes. 761 pp. Sceaux.

Breitenbach, J. \& Kränzlin, F. 1986: Fungi of Switzerland 2. Non gilled fungi. Heterobasidiomycetes, Aphyllophorales, Gasteromycetes. - 412 pp. Luceme.

Christiansen, M.P. 1959: Danish resupinate fungi 1. Ascomycetes and Heterobasidiomycetes. - Dansk Bot. Ark. 19:1-55.

Christiansen, M.P. 1960: Danish resupinate fungi 2. Homobasidiomycetes. - Dansk Bot. Ark. 19:56-388.

Cunningham, G.H. 1955: Thelephoraceae of New Zealand 6. The genus Peniophora. - Trans. Royal Soc. New Zealand 83:247-293.

David, A. 1982: Étude monographique du genre Skeletocutis (Polyporaceae). - Naturaliste Canadien 109:235-272.

Doll, R. 1977: Neufunde für die Mykoflora der DDR. - Z. Pilzkunde 43:197-207.

Doll, R. 1979: Die Vegetation der "Kalkhorst" bei Neusterlitz. - Natur Naturschutz Mecklenburg 15:17-61.

Doll, R. 1981: Mykologische Notizen aus Mecklenburg 5. Mykol. Mitteilungsbl. 25:55-63.

Dueñas, M. 1986: Algunos Aphyllophorales interesantes del norte de España. - Micol. Madrid 11:125-131.

Dueñas, M. \& Tellería, M.T. 1984: Notas sobre algunos Aphyllophorales procedentes del norte de España. - Bol. Soc. Micol. Castellana 8:51-60.

Dueñas, M. \& Tellería, M.T. 1985: Algunos Aphyllophorales del sabinar de Mirantes de Luna (León). - Bol. Soc. Micol. Castellana 10:47-54.

Dueñas, M. \& Tellería, M.T. 1988: Catálogo de los corticiáceos y poliporáceos, s.l. (Aphyllophorales, Basidiomycotina), de la microflora Cántabro-Astur. - Ruizia 5:1-262.

Eriksson, J. 1948: Något om Hallands Väderös vedbeboende basidiomyceter. - Kungl. Fysiografiska Sällsk. Lund Förhandl. 18:1-21.

Eriksson, J. 1954: Ramaricium n.gen., a corticoid member of the Ramaria group. - Svensk Bot. Tidskr. 48:188-198.

Eriksson, J. 1958a: Studies in the Heterobasidiomycetes and Homobasidiomycetes-Aphyllophorales of Muddus National Park in North Sweden. - Symb. Bot. Upsal. 16(1): $1-172,24$ pls.

Eriksson, J. 1958b: Studies in Corticiaceae (Botryohypochnus Donk, Botryobasidium Donk, and Gloeocystidiellum Donk). - Svensk Bot. Tidskr. 52:1-17.
Eriksson, J., Hjortstam, K. \& Ryvarden, L. 1984: The Corticiaceae of North Europe 7. Schizopora-Suillosporium. Pp. 1281-1449. Oslo.

Eriksson, J. \& Ryvarden, L. 1973: The Corticiaceae of North Europe 2. Aleurodiscus-Confertobasidium. - Pp. 57-261. Oslo.

Eriksson, J. \& Ryvarden, L. 1975: The Corticiaceae of North Europe 3. Coronicium-Hyphoderma. - Pp. 547-886. Oslo.

Eriksson, J. \& Ryvarden, L. 1976: The Corticiaceae of North Europe 4. Hyphodermella-Mycoacia. - Pp. 887-1047. Oslo.

Eriksson, J. \& Strid, Å. 1969: Studies in the Aphyllophorales (Basidiomycetes) of northern Finland. - Rep. Kevo Subarctic Sta. 4:112-158.

Gilbertson, R.L. 1974: Fungi that decay ponderosa pine. 197 pp. Tucson. AZ.

Gilbertson, R.L. \& Blackwell, M. 1987: Notes on wood-rotting fungi of junipers in the Gulf Coast region 2. - Mycotaxon 28:369-402.

Gilbertson, R.L. \& Budington, A.B. 1970: New records of Arizona wood-rotting fungi. - J. Arizona Acad. Sci. 6:91-97.

Ginns, J.H. 1986: Compendium of plant disease and decay fungi in Canada 1960-1980. - 416 pp. Ottawa.

Hallenberg, N. 1973: The Fennoscandian species of Asterostroma. - Göteborgs Svampkl. Årsskrift 1972-73: 35-43.

Hallenberg, N. 1978: Wood-fungi (Corticiaceae, Coniophoraceae, Lachnocladiaceae, Thelephoraceae) in N. Iran 1. - Iran. J. Plant Pathol. 14:38-87.

Hallenberg, N. 1981: Synopsis of wood-inhabiting Aphyllophorales (Basidiomycetes) and Heterobasidiomycetes from N. Iran. - Mycotaxon 12:473-502.

Hallenberg, N. 1984a: Compatibility between species of Corticiaceae s.l. (Basidiomycetes) from Europe and North America. - Mycotaxon 21:335-388.

Hallenberg, N. 1984b: A taxonomic analysis of the Sistotrema brinkmannii complex (Corticiaceae, Basidiomycetes). - Mycotaxon 21:389-411.

Hallenberg, N. 1985: Compatibility between species of Corticiaceae s.l. (Basidiomycetes) from Europe and Canada 2. Mycotaxon 24:437-443.

Hallenberg, N. 1986: Cultural studies in Tubulicrinis and Xenasmatella (Corticiaceae, Basidiomycetes). - Mycotaxon 27:361-375.

Hallenberg, N. \& Hjortstam, K. 1990: Hypochnicium erikssonii sp. nov. instead of $\mathrm{H}$. sphaerosporum - a necessary name alteration. - Windahlia 18:43-45.

Hallenberg, N. \& Michelitsch, S. 1983: Wood-fungi from Styria, Austria. - Windahlia 12-13: 39-56.

Hallenberg, N. \& Sunhede, S. 1979: Notes on the wood fungus flora of Hallands Väderö. - Göteborgs Svampkl. Årsskrift 1979:67-85.

Heikinheimo, O. \& Raatikainen, M. 1971: Paikan ilmoittaminen Suomesta talletetuissa biologisissa aineistoissa . Ann. Entomol. Fennici 37(1): 1-27.

Hjortstam, K. 1973: Studies in the Corticiaceae (Basidiomycetes) and related fungi of Västergötland in Southwest Sweden 1. - Svensk Bot. Tidskr. 67:97-126.

Hjortstam, K. 1979a: A synopsis of the genus Tubulicrinis Donk sensu stricto (Corticiaceae). - Göteborgs Svampkl. Årsskrift 1979: 45-61.

Hjortstam, K. 1979b: Vedbeboende svampar från Råbäck på Kinnekulle. - Svensk Bot. Tidskr. 72:321-326. 
Hjortstam, K. 1981: Notes on Corticiaceae (Basidiomycetes) 9. Three new combinations in Hypochniciellum. - Mycotaxon 13:124-126.

Hjortstam, K. 1983: Notes on Corticiaceae (Basidiomycetes) 12. - Mycotaxon 17:577-584.

Hjortstam, K. 1984: Corticiaceous fungi of northern Europe - check-list of the species in the nordic countries. Windahlia 14:1-29.

Hjortstam, K. 1986: Hypochnicium subrigescens, a new species of northern Europe. - Windahlia 16:69-71.

Hjortstam, K. 1987: Studies in tropical Corticiaceae (Basidiomycetes) 7. Specimens from East Africa, collected by L. Ryvarden 2. - Mycotaxon 28:19-37.

Hjortstam, K. \& Bononi, V.R.L. 1987: A contribution to the knowledge of Corticiaceae s.l. (Aphyllophorales) in Brazil. - Mycotaxon 28:1-15.

Hjortstam, K. \& Larsson, K.-H. 1978: Notes on Corticiaceae (Basidiomycetes) 2. - Mycotaxon 7:117-124.

Hjortstam, K. \& Larsson, K.-H. 1986: Notes on Corticiaceae (Basidiomycetes) 15. Some new species from northem Europe. - Mycotaxon 26:437-443.

Hjortstam, K., Larsson, K.-H. \& Ryvarden, L. 1988: The Corticiaceae of North Europe 8. Thanathephorus - Ypsilonidium. - Pp. 1449-1631. Oslo.

Hjortstam, K. \& Ryvarden, L. 1985: New and noteworthy Basidiomycetes (Aphyllophorales) from Tierra del Fuego, Argentine. - Mycotaxon 22:159-167.

Hjortstam, K., Tellería, M.T, Ryvarden, L. \& Calogne, F.D. 1981: Notes on the Aphyllophorales of Spain 2. Nova Hedwigia 34:525-538.

v. Höhnel, F. \& Litschauer, V. 1908: Beiträge zur Kenntnis der Corticieen 3. - Sitzungsber. König. Akad. Wiss. Wien, Math.-Nat. K1. 117:1081-1124.

Holmgren, P., Keuken, W. \& Schofield, E. 1981: Index herbariorum 1. The herbaria of the world. Ed. 7. - Regnum Vegetabile 106:1-452.

Jackson, H.S. 1949: Studies of Canadian Thelephoraceae 4. Corticium anceps in North America. - Canadian J. Res. C 27:241-252.

Jülich, W. 1972: Monographie der Athelieae (Corticiaceae, Basidiomycetes). - Willdenowia 7 (Beih.): 1-283.

Jülich, W. 1979: Studies in resupinate Basidiomycetes 4. Persoonia 10:325-336.

Jülich, W. 1984: Die Nichtblătterpilze, Gallertpilze und Bauchpilze (Aphyllophorales, Heterobasidiomycetes, Gasteromycetes). - In: Gams, H. (ed.), Kleine Kryptogamenflora $2 \mathrm{~b}(1)$, Basidiomyceten 1. $626 \mathrm{pp}$. Stuttgart \& New York.

Jülich, W. \& Stalpers, J.A. 1980: The resupinate non-poroid Aphyllophorales of the Temperate Northem Hemisphere. - Verh. Koninkl. Nederlandse Akad. Wetensch. Afd. Nat., Tweede Reeks, 74:1-335.

Keller, J. 1979: Ultrastructure des hyphes incrustées dans le genre Skeletocutis. - Persoonia 10:347-355.

Kotiranta, H. 1984: Skeletocutis jelicii: a new member of the Finnish polypore flora. - Karstenia 24:73-76.

Kotiranta, H. \& Larsson, K.-H. 1990: New or little collected corticolous fungi from Finland (Aphyllophorales, Basidiomycetes). - Windahlia 18:1-14.

Kreisel, H. 1987: Pilzflora der Deutschen Demokratischen Republik. -281 pp. Jena.
Larsson, K-H. 1986 (1985): Wood-inhabiting, resupinate basidiomycetes from Halleberg and Hunneberg in Västergötland, southwest Sweden. - Windahlia 15:23-34.

Liberta, A.E. 1962 (1960): A taxonomic analysis of the section Athele of the genus Corticium 1. Genus Xenasma. Mycologia 52:884-914.

Liberta, A.E. 1964: Notes on Illinois resupinate Hymenomycetes. - Mycologia 56:249-252.

Liberta, A.E. 1966: Resupinate hymenomycetes from Gaspé and adjacent counties (Canada) 1. - Mycologia 58: 927-933.

Liberta, A.E. 1973: The genus Trechispora (Basidiomycetes, Corticiaceae). - Canad. J. Bot. 51:1871-1892.

Litschauer, V. 1941: Neue schwedische Corticieen aus dem Herbar L. Romell's. - Ann. Mycol. 39:117-135.

Manjón, J.L. \& Moreno, G. 1983: Estudios sobre Aphyllophorales 3. Fructificaciones en Abies pinsapo Boiss. Cryptog. Mycol. 4:145-156.

Martin, K.J. \& Gilbertson, R.L. 1977: Synopsis of woodrotting fungi on spruce in North America 1. - Mycotaxon 6:43-77.

Niemelä, T. 1982: Polypore survey of Finland 1. Introduction. - Karstenia 22:21-26.

Niemelä, T. 1985: On Fennoscandian polypores 9. Gelatoporia n.gen. and Tyromyces canadensis, plus notes on Skeletocutis and Antrodia. - Karstenia 25:21-40.

Niemelä, T. \& Kotiranta, H. 1982: Polypore survey of Finland 2. The genus Phellinus. - Karstenia 22:27-42.

Niemelä, T. \& Saarenoksa, R. 1985: Dentipellis fragilis and Steccherinum oreophilum: Finnish records of hydnaceous fungi. - Karstenia 25:70-74.

Oberwinkler, F. 1966a (1965): Die Gatung Tubulicrinis Donk (Corticiaceae). - Z. Pilzkunde 31:12-48.

Oberwinkler, F. 1966b (1965): Primitive Basidiomyceten. Revision einiger Formenkreise von Basidienpilzen mit plastischer Basidie. - Sydowia 19:1-72, 21 pls.

Parmasto, E. 1965: Corticiaceae U.R.S.S. 2. - Eesti NSV Tead. Akad. Toim., Biol. Seer. 14:315-319.

Parmasto, E. 1966: Corticiaceae U.R.S.S. 3. - Eesti NSV Tead. Akad. Toim., Biol. Seer. 15:372-373.

Parmasto, E. 1967: Corticiaceae U.R.S.S. 4. Descriptiones taxorum novorum. Combinationes novae. - Eesti NSV Tead. Akad. Toim., Biol. Seer. 16:377-394.

Parmasto, E. 1968: Conspectus systematis Corticiacearum. $261 \mathrm{pp}$. Tartu.

Parmasto, E. 1971 (1970): The Lachnocladiaceae of Soviet Union. - 168 pp., 35 pls. Tartu.

Strid, A. 1973: Notes on lignicolous Aphyllophorales in the province of Dalarna and in Sonfjället National Park in Hărjedalen (Central Sweden). - Göteborgs Svampkl. Årsskr. 1972-73:5-30.

Strid, A. 1975a: Wood-inhabiting fungi of alder forests in North-Central Scandinavia 1. Aphyllophorales (Basidiomycetes). Taxonomy, ecology and distribution. - Wahlenbergia 1:1-237.

Strid, A. 1975b: Lignicolous and corticolous fungi in alder vegetation in Central Norway with special reference to Aphyllophorales (Basidiomycetes). - Kongel. norske Vidensk. Selsk. Skr. 4:1-52.

Tellería, M.T. \& Truchero, M.F. 1981: Estudio sobre los Aphyllophorales (Basidiomycetes) lignicolas de la Sierra de 
Guadarrama. - Bol. Soc. Micol. Cast. 6:63-91.

Ulvinen, T., Ohenoja, E., Ahti, T. \& Alanko, P. 1981: A check-list of the fungi (incl. lichens) of the Koillismaa (Kuusamo) biological province, N.E. Finland. - Oulanka Reports 2:1-64.

Weresub, L.K. 1953: Studies of Canadian Thelephoraceae 10. Some species of Peniophora, section Tubuliferae. - Cana- dian J. Bot. 31:760-778.

Weresub, L.K. \& LeClair, P.M. 1971: On Papulaspora and bulbilliferous basidiomycetes Burgoa and Minimedusa. Canadian J. Bot. 49:2203-2213.

Received on 18 June 1990 